\title{
Rumen digestion kinetics, microbial yield, and omasal flows of nonmicrobial, bacterial, and protozoal amino acids in lactating dairy cattle fed fermentation by-products or urea as a soluble nitrogen source
}

\author{
S. W. Fessenden, ${ }^{1}$ T. J. Hackmann, ${ }^{2}$ D. A. Ross, ${ }^{1}$ E. Block, ${ }^{3}$ A. Foskolos, ${ }^{1}$ and M. E. Van Amburgh ${ }^{1 *}$ \\ ${ }^{1}$ Department of Animal Science, Cornell University, Ithaca, NY 14850 \\ ${ }^{2}$ Department of Animal Sciences, University of Florida, Gainesville 32611 \\ ${ }^{3}$ Arm and Hammer Animal Nutrition, Princeton, NJ 08543
}

\section{ABSTRACT}

The objective of this study was to evaluate the effect of a fermentation by-product on rumen function, microbial yield, and composition and flows of nutrients from the rumen in high-producing lactating dairy cattle. Eight ruminally cannulated multiparous Holstein cows averaging (mean \pm standard deviation) $60 \pm 10 \mathrm{~d}$ in milk and $637 \pm 38 \mathrm{~kg}$ of body weight were randomly assigned to 1 of 2 treatment sequences in a switchback design. Treatment diets contained (dry matter basis) $44 \%$ corn silage, $13 \%$ alfalfa silage, $12 \%$ ground corn, and $31 \%$ protein premix, containing either a control mix of urea and wheat middlings $(\mathrm{CON})$ or a commercial fermentation by-product meal (Fermenten, Arm and Hammer Animal Nutrition, Princeton, NJ) at $3 \%$ diet inclusion rate (EXP). The trial consisted of three 28-d experimental periods, where each period consisted of $21 \mathrm{~d}$ of diet adaptation and $7 \mathrm{~d}$ of data and sample collection. A triple-marker technique and double-labeled ${ }^{15} \mathrm{~N}^{15} \mathrm{~N}$-urea were used to were used to measure protozoal, bacterial, and nonmicrobial omasal flow of AA. Rumen pool sizes and omasal flows were used to determine digestion parameters, including fractional rates of carbohydrate digestion, microbial growth, and yield of microbial biomass per gram of degraded substrate. Fermentation by-product inclusion in EXP diets increased microbial $\mathrm{N}$ and amino acid $\mathrm{N}$ content in microbes relative to microbes from $\mathrm{CON}$ cows fed the urea control. Microbial AA profile did not differ between diets. Daily omasal flows of AA were increased in EXP cows as a result of decreased degradation of feed protein. The inclusion of the fermentation by-product increased nonmicrobial AA flow in cows fed EXP versus CON. Average protozoal contribution to

Received July 26, 2018.

Accepted November 18, 2018.

*Corresponding author: mev1@cornell.edu microbial $\mathrm{N}$ flow was $16.8 \%$, yet protozoa accounted for $21 \%$ of the microbial AA flow, with a range of 8 to $46 \%$ for individual AA. Cows in this study maintained an average rumen pool size of $320 \mathrm{~g}$ of microbial $\mathrm{N}$, and bacterial and protozoal pools were estimated at 4 different theoretical levels of selective protozoa retention. Fractional growth rate of all microbes was estimated to be $0.069 \mathrm{~h}^{-1}$, with a yield of $0.44 \mathrm{~g}$ of microbial biomass per gram of carbohydrate degraded. Results indicated that fermentation by-product can increase omasal flow of AA while maintaining adequate rumen $\mathrm{N}$ available for microbial growth and protein synthesis. Simulations from a developmental version of the Cornell Net Carbohydrate and Protein System indicated strong agreement between predicted and observed values, with some areas key for improvement in AA flow and bacterial versus protozoal $\mathrm{N}$ partitioning.

Key words: rumen protozoa, amino acids, microbial growth, Cornell Net Carbohydrate and Protein System, Fermenten

\section{INTRODUCTION}

By-products of human food production have successfully been used to improve the sustainability of the dairy industry (VandeHaar and St-Pierre, 2006). Efficient and effective use of by-product feeds requires adequate knowledge of the fermentation characteristics of the feed (Fessenden and Van Amburgh, 2016). Fermenten (Arm and Hammer Animal Nutrition, Princeton, NJ) is a commercially available fermentation by-product feed derived from glutamic acid production that contains high amounts of rumen-available nitrogen compounds in the form of soluble AA and small peptides (Fessenden, 2016). Lean et al. (2005) reported an increase in microbial protein flow from continuous fermenters fed fermentation by-product. Those authors attributed this increase in microbial biomass to stimulation of microbial protein synthesis by small peptides and AA (Cotta and Russell, 1982). However, experiments on the same 
by-products in vivo have not demonstrated consistent production responses (Broderick et al., 2000; Penner et al., 2009). In a companion paper, Fessenden et al. (2019) demonstrated that fermentation by-product decreased dietary protein degradation in the rumen by approximately $15 \%$, indicating a possible sparing effect of degradable protein through an unknown mechanism. The results from the first portion of the study warranted further investigation into possible effects on omasal AA flow, the partition of $\mathrm{N}$ flows between microbial and nonmicrobial fractions, and the effects on microbial growth and digestion parameters.

Mathematical models such as the Cornell Net Carbohydrate and Protein system (CNCPS; Higgs et al., 2015; Van Amburgh et al., 2015) have been successfully used to optimize rumen microbial output and meet animal nutrient requirements while reducing $\mathrm{N}$ losses to the environment (Tylutki et al., 2008). A new, dynamic and more mechanistic version of the CNCPS was developed (Higgs, 2014) to describe rumen degradation of substrates with mechanistic representations of growth of bacteria and protozoa and include interactions among protozoa and bacteria such as predation and intraruminal microbial $\mathrm{N}$ turnover. Evaluations of this model indicated a strong ability to predict the partitioning between microbial and nonmicrobial nitrogen flows; however, the partitioning between protozoa and bacteria along with individual AA predictions might require further refinement. As with most model development, evaluations of the rumen submodel with independent data can be helpful for determining areas for improvement.

The hypothesis of the current study was that the decreased ruminal protein degradation associated with fermentation by-product inclusion would increase total AA flow at the omasal canal, with limited effects on bacteria and protozoa growth and turnover. This hypothesis was based off the previous findings regarding microbial and nonmicrobial $\mathrm{N}$ flows reported in the companion paper (Fessenden et al., 2019). Our objectives were to (1) evaluate the effect of urea with wheat middlings or commercial fermentation by-product on omasal flows of nonmicrobial, bacterial, and protozoal flows of AA and (2) provide comparisons of modelpredicted versus measured values for rumen microbial digestion and growth parameters.

\section{MATERIALS AND METHODS}

The experiment was conducted from April to July 2014 at the Cornell University Ruminant Center in Harford, New York. All animals involved in this experiment were cared for according to the guidelines of the Cornell University Animal Care and Use committee.
The committee reviewed and approved the experiment and all procedures carried out in the study.

\section{Animals, Treatments, and Experimental Design}

Eight ruminally cannulated multiparous Holstein cows averaging (mean $\pm \mathrm{SD}$ ) $60 \pm 10 \mathrm{DIM}$ and 637 $\pm 38 \mathrm{~kg}$ of $\mathrm{BW}$ were enrolled in the study. All cows were allowed a 3 -wk pretrial acclimation period, where animals were managed and housed in a tiestall and individually fed a common diet. Cattle were then stratified by pretrial milk production and randomly assigned to 1 of 2 treatment sequences in a switchback design with three 28-d periods. Each period contained $21 \mathrm{~d}$ for diet adaptation and $7 \mathrm{~d}$ of data and sample collection. Treatment diets contained (DM basis) $44 \%$ corn silage, $13 \%$ alfalfa silage, $12 \%$ ground corn, and $31 \%$ protein premix containing either a control mix of urea and wheat middlings $(\mathbf{C O N})$ or Fermenten (EXP) at a $3 \%$ inclusion rate in the final diet (Table 1). All cattle received both diets throughout the 3 experimental periods according to their randomly assigned sequence of either EXP-CON-EXP or CON-EXP-CON (switchback design). Diets were formulated using CNCPS v. 6.5 (Van Amburgh et al., 2015). Full details of the cattle housing, milking, and feeding management are described in Fessenden et al. (2019).

\section{Sample Collection and Processing}

Digesta flow leaving the rumen was quantified using the omasal sampling technique developed by Huhtanen et al. (1997) and adapted by Reynal and Broderick (2005). A triple marker system using CoEDTA (Udén et al., 1980), $\mathrm{YbCl}_{3}$ (modified from Siddons et al., 1985), and undigested amylase- and sodium sulfitetreated NDF corrected for ash residue (uNDFom; Raffrenato et al., 2018) was used to quantify liquid, small particle, and large particle flow at the omasal canal, respectively. Double-labeled urea $\left({ }^{15} \mathrm{~N}^{15} \mathrm{~N}\right.$-urea, 98\% purity, Cambridge Isotope Laboratories Inc., Andover, MA) was infused into the jugular vein for use as a microbial marker following the method used for studies on urea recycling (Lobley et al., 2000). Details on marker preparation and infusion are reported in Fessenden et al. (2019).

Samples of whole omasal contents were collected from the omasal canal at 2 -h intervals during three 8 -h sessions at $1600,1800,2000$, and $2200 \mathrm{~h}$ on $\mathrm{d} 24$; at 0000, 0200, 0400, and $0600 \mathrm{~h}$ on d 26; and at 0800, 1000,1200 , and $1400 \mathrm{~h}$ on d 27. Sampling times were chosen to encompass every $2 \mathrm{~h}$ of the average 24-h feeding cycle. During each 8-h session, a $425-\mathrm{mL}$ spot sample was obtained at the first 3 time points, whereas 
Table 1. Ingredient and nutrient composition (mean $\pm \mathrm{SD})^{1}$ of experimental diets

\begin{tabular}{|c|c|c|}
\hline \multirow[b]{2}{*}{ Item } & \multicolumn{2}{|c|}{ Diet } \\
\hline & $\mathrm{CON}$ & EXP \\
\hline \multicolumn{3}{|l|}{ Ingredient, $\%$ of $\mathrm{DM}$} \\
\hline Corn silage & 44.6 & 44.6 \\
\hline Alfalfa silage & 12.0 & 12.0 \\
\hline Corn meal & 12.0 & 12.0 \\
\hline Expeller soybean meal $^{2}$ & 8.0 & 8.0 \\
\hline Soybean hulls & 5.8 & 5.8 \\
\hline Citrus pulp, dry & 3.3 & 3.3 \\
\hline Chocolate meal & 2.4 & 2.4 \\
\hline $\mathrm{SFA}^{3}$ & 1.2 & 1.2 \\
\hline Molasses & 0.9 & 0.9 \\
\hline Blood meal & 1.7 & 1.7 \\
\hline Wheat middlings & 4.8 & 3.2 \\
\hline Fermentation by-product ${ }^{4}$ & - & 3.0 \\
\hline Calcium carbonate & - & 0.7 \\
\hline Urea & 0.4 & - \\
\hline Calcium sulfate, dihydrate & 1.7 & - \\
\hline Sodium bicarbonate & 0.33 & 0.40 \\
\hline Salt white & 0.30 & 0.32 \\
\hline Magnesium oxide & 0.17 & 0.17 \\
\hline Dicalcium phosphate & 0.16 & 0.16 \\
\hline Supplemental methionine ${ }^{5}$ & 0.06 & 0.06 \\
\hline Vitamin and mineral mix ${ }^{6}$ & 0.18 & 0.18 \\
\hline \multicolumn{3}{|l|}{ Nutrient composition } \\
\hline $\mathrm{DM}, \%$ & $44.5 \pm 0.7$ & $44.2 \pm 0.8$ \\
\hline $\mathrm{OM}, \%$ of DM & $93.9 \pm 0.3$ & $93.8 \pm 0.6$ \\
\hline $\mathrm{CP}, \%$ of $\mathrm{DM}$ & $15.9 \pm 0.6$ & $16.1 \pm 0.5$ \\
\hline $\mathrm{RDP}^{7} \%$ of DM & $8.4 \pm 0.1$ & $8.0 \pm 0.1$ \\
\hline Starch, \% of DM & $27.5 \pm 1.1$ & $27.8 \pm 0.5$ \\
\hline Sugars, \% of DM & $5.4 \pm 0.4$ & $5.3 \pm 0.3$ \\
\hline $\mathrm{NFC},{ }^{7} \%$ of DM & $41.7 \pm 0.2$ & $41.8 \pm 1.3$ \\
\hline aNDFom, ${ }^{8} \%$ of DM & $30.9 \pm 0.2$ & $31.2 \pm 0.2$ \\
\hline $\mathrm{ADF}, \%$ of $\mathrm{DM}$ & $19.9 \pm 1.5$ & $19.7 \pm 0.6$ \\
\hline $\mathrm{ADL}, \%$ of NDF & $10.0 \pm 0.9$ & $10.0 \pm 1.4$ \\
\hline Ether extract, \% of DM & $5.0 \pm 0.2$ & $4.9 \pm 0.2$ \\
\hline $\mathrm{ME},{ }^{7} \mathrm{Mcal} / \mathrm{kg}$ & $2.5 \pm 0.1$ & $2.5 \pm 0.1$ \\
\hline
\end{tabular}

${ }^{1}$ Analyzed values from 3 period composite samples. Table is from Fessenden et al. (2019).

${ }^{2}$ Soyplus (West Central Cooperative, Ralston, IA).

${ }^{3}$ Energy Booster 100 (MSC Company, Eden Prairie, MN).

${ }^{4}$ Fermenten (Arm and Hammer Animal Nutrition, Princeton, NJ).

${ }^{5}$ Smartamine M (Bluestar Adisseo Nutrition Group, Alpharetta, GA).

${ }^{6}$ Provided (per $\mathrm{kg}$ of diet DM): $44 \mathrm{mg}$ of $\mathrm{Zn}, 32 \mathrm{mg}$ of Mn, $10 \mathrm{mg}$ of $\mathrm{Cu}, 1 \mathrm{mg}$ of $\mathrm{Co}, 1 \mathrm{mg}$ of I, $0.3 \mathrm{mg}$ of Se, $5000 \mathrm{IU}$ of vitamin A, $980 \mathrm{IU}$ of vitamin $\mathrm{B}$, and $25 \mathrm{IU}$ of vitamin $\mathrm{E}$.

${ }^{7}$ Calculated by the Cornell Net Carbohydrate and Protein System v. 6.5 (van Amburgh et al., 2015).

${ }^{8}$ aNDFom $=$ amylase- and sodium sulfite-treated NDF corrected for ash residue.

$675 \mathrm{~mL}$ were taken at the last time point. Spot samples were split into subsamples of $50(\times 2), 125$, and $200 \mathrm{~mL}$, with an additional $250-\mathrm{mL}$ subsample at the last time point. The $50-\mathrm{mL}$ subsamples were used for a separate study of nutrient flows (Fessenden et al., 2019). The 125-mL subsamples were held on ice and combined within session, yielding a 500-mL sample for bacterial isolation. The $200-\mathrm{mL}$ samples were combined within period and stored at $-20^{\circ} \mathrm{C}$, yielding a $2.4-\mathrm{L}$ composite for digestion phase separation. The additional 250-mL sample obtained at the end of each session was strained through 2 layers of cheesecloth and immediately processed to isolate protozoa (described later).

The 2.4-L pooled omasal composites were thawed and separated into omasal large particle $(\mathbf{L P})$, small particle (SP), and liquid phase (LQ), as described in the companion paper (Fessenden et al., 2019). All phase samples were freeze-dried and either ground through a 1-mm screen on a Wiley mill (LP; Thomas Scientific, Swedesboro, NJ) or homogenized with a mortar and pestle (SP and LQ) before analysis. Concentrations of $\mathrm{Yb}, \mathrm{Co}$, and $\mathrm{uNDF}$ in each phase were used to calculate the concentration of each nutrient in a theoretical entity representing omasal true digesta (OTD; France and Siddons, 1986). As such, the reported flows and concentrations of any given nutrient in OTD is a mathematical calculation based on reconstitution factors determined using the triple marker technique and measured values of the nutrient in LQ, SP, and LP. This mathematical construct is referred to in this paper as OTD. On the last day of each period, rumen contents were evacuated, weighed, mixed, and a representative sample was obtained for pool size determinations and stored at $-20^{\circ} \mathrm{C}$ before lyophilization and determination of rumen nutrient pool sizes.

The bacterial isolations from each 8-h sampling period were combined within period to yield an omasal bacteria sample for each cow within period. Microbial isolation was performed according to Whitehouse et al. (1994) with modifications. Briefly, whole omasal contents were filtered through 4 layers of cheesecloth and solids were rinsed once with saline, and the filtrate (I) was treated with formalin $(0.1 \% \mathrm{vol} / \mathrm{vol}$ in final solution) and stored at $4^{\circ} \mathrm{C}$. The solids retained on the cheesecloth were incubated for $1 \mathrm{~h}$ at $39^{\circ} \mathrm{C}$ in a $0.1 \%$ methylcellulose solution, mixed for $1 \mathrm{~min}$ at low speed (Omni Mixer, Omni International, Kennesaw, GA) to detach solids associated bacteria, and held at $4^{\circ} \mathrm{C}$ for $24 \mathrm{~h}$. The contents were then squeezed through 4 layers of cheesecloth and the filtrate (II) was treated with formalin $(0.1 \% \mathrm{vol} / \mathrm{vol}$ in final solution). Filtrates I and II were held at $4^{\circ} \mathrm{C}$ until the end of the sampling period, then combined and centrifuged at 1,000 $\times g$ for $5 \mathrm{~min}$ at $4^{\circ} \mathrm{C}$ to remove small feed particles. The supernatant was centrifuged at $15,000 \times g$ for $20 \mathrm{~min}$ at $4^{\circ} \mathrm{C}$ and the bacterial pellet, representing both solid- and liquidassociated bacteria, was collected and stored at $-20^{\circ} \mathrm{C}$ until lyophilization and later analysis.

Protozoa were isolated from whole omasal contents using the procedure described by Denton et al. (2015) with modifications (Figure 1). Strained omasal fluid $(250 \mathrm{~mL})$ was combined 1:1 with prewarmed, anaerobically prepared Simplex-type buffer (Williams and 
Coleman, 1992) and added to a prewarmed separatory funnel. Plant particles were removed by aspiration after $1 \mathrm{~h}$ of incubation at $39^{\circ} \mathrm{C}$, allowing for removal of 50 $\mathrm{mL}$ of fluid to a precalibrated $450-\mathrm{mL}$ line on the funnel. Funnel contents were then preserved with formalin $(0.1 \% \mathrm{vol} / \mathrm{vol}$ in final solution $)$ and stored for $<4 \mathrm{~d}$ at $4^{\circ} \mathrm{C}$. At the end of each sampling period, preserved contents were centrifuged at $1,000 \times g$ for 5 min at $4^{\circ} \mathrm{C}$, the pellet was resuspended in saline, and protozoa were isolated on a nylon cloth with a $20-\mu \mathrm{m}$ pore size $(14 \%$ open area, Sefar, Buffalo, NY). The protozoal isolate was washed with saline $(500 \mathrm{~mL})$ to reduce bacterial contamination. Microscopic inspection of the retained protozoa and filtrate indicated low feed contamination and good recovery of small protozoa. After isolation, protozoa were stored at $-20^{\circ} \mathrm{C}$, followed by lyophilization and measurement of DM to calculate yield of protozoal DM per liter of omasal fluid (Ahvenjärvi et al., 2002).

\section{Sample Analysis}

Samples of freeze-dried bacterial, protozoal, omasal fractions, and rumen contents were analyzed for residual DM after $6 \mathrm{~h}$ at $105^{\circ} \mathrm{C}$ and ash according to AOAC International (2005). Total N was determined using a combustion assay (Leco FP-528 N Analyzer, Leco Corp., St. Joseph, MI). Samples were analyzed for NAN and ${ }^{15} \mathrm{~N}$ by weighting $20 \mu \mathrm{g}$ of $\mathrm{N}$ from each sample into tin capsules, adding $10 \mu \mathrm{L}$ of $72 \mathrm{mM} \mathrm{K}_{2} \mathrm{CO}_{3}$, and incubating at $60^{\circ} \mathrm{C}$ overnight to volatilize ammonia. Samples were then analyzed for NAN and ${ }^{15} \mathrm{~N}$ using a Carlo Erba NC2500 elemental analyzer (Thermoquest, Milan, Italy) interfaced with an isotope ratio mass spectrometer (Cornell University Stable Isotope Laboratory, Ithaca, NY).

Amino acid content of bacterial, protozoal, and omasal fractions was determined by HPLC. For all AA, excluding Met, Cys, and Trp, a sample containing 2 $\mathrm{mg}$ of $\mathrm{N}$ was weighed into hydrolysis tubes with 25 $\mu \mathrm{L}$ of $250 \mathrm{~m} M$ norleucine as an internal standard. Samples were then hydrolyzed at $110^{\circ} \mathrm{C}$ for $21 \mathrm{~h}$ in a block heater (Gehrke et al., 1985) with high-purity 6 $M \mathrm{HCl}(5 \mathrm{~mL})$ after flushing with $\mathrm{N}_{2}$ gas. For Met and Cys, aliquots containing $2 \mathrm{mg}$ of $\mathrm{N}$ and the internal standard were preoxidized with $1 \mathrm{~mL}$ of performic acid ( $0.9 \mathrm{~mL}$ of $88 \%$ formic acid, $0.1 \mathrm{~mL}$ of $30 \% \mathrm{H}_{2} \mathrm{O}_{2}$, and 5 $\mathrm{mg}$ of phenol) for $16 \mathrm{~h}$ at $4^{\circ} \mathrm{C}$ before acid hydrolysis, as described above (Mason et al., 1980; Elkin and Griffith, 1985). After hydrolysis, tube contents were filtered through Whatman 541 filter paper (GE Healthcare UK Ltd., Buckinghamshire, UK) and filtrate was diluted to $50 \mathrm{~mL}$ in a volumetric flask with HPLC-grade
$\mathrm{H}_{2} \mathrm{O}$. Aliquots $(0.5 \mathrm{~mL})$ were evaporated at $60^{\circ} \mathrm{C}$ under constant $\mathrm{N}_{2}$ flushing, with 3 rinses and re-evaporations with HPLC-grade $\mathrm{H}_{2} \mathrm{O}$ to remove acid residues. After final evaporation, hydrolysate was dissolved in $1 \mathrm{~mL}$ of $\mathrm{Na}$ diluent (Na220, Pickering Laboratories, Mountain View, CA).

Individual AA hydrolysates were separated using an Agilent 1100 series HPLC (Agilent Technologies, Santa Clara, CA) fitted with a sodium cation exchange column (Cat. no 1154110T, Pikering Laboratories) using a 4-buffer step gradient and column temperature gradient. Detection of separated AA was performed at $560 \mathrm{~nm}$ following postcolumn ninhydrin derivation. Standards $(125 \mu M)$ for the individual AA were prepared by diluting a pure standard in sample buffer. The volume of sample and standards loaded onto the column was $10 \mu \mathrm{L}$. For Trp determination, a separate aliquot of sample containing $2 \mathrm{mg}$ of $\mathrm{N}$ was hydrolyzed with $1.2 \mathrm{~g}$ of $\mathrm{Ba}(\mathrm{OH})_{2}$ at $110^{\circ} \mathrm{C}$ for $16 \mathrm{~h}$ on a block heater according to the method of Landry and Delhaye (1992). Included in the hydrolysis was $125 \mu \mathrm{L}$ of 5 -methyl-Trp $(5 \mathrm{mM})$ as an internal standard. After cooling to precipitate barium ions, an aliquot $(3 \mu \mathrm{L})$ of the hydrolysate was added to $1 \mathrm{~mL}$ of acetate buffer (0.07 $M$ sodium acetate) and analyzed using fluorescence detection $($ excitation $=285 \mathrm{~nm}$, emission $=345$ $\mathrm{nm})$ after HPLC separation.

\section{Calculations}

Calculation of ${ }^{15} \mathrm{~N}$ atom percent excess (APE) in rumen contents, omasal fractions, and microbial samples; omasal nutrient flow and partitioning of NAN are described in the companion paper (Fessenden et al., 2019). Briefly, total $\mathrm{N}$ entering the omasal canal was partitioned into 3 fractions: ammonia $\mathrm{N}$, microbial $\mathrm{N}$, and nonammonia nonmicrobial N. Total NAN flow was calculated as the difference between total $\mathrm{N}$ and ammonia N.

The $\mathrm{N}$ content of bacteria and protozoa was used to calculate flow of OM and DM in each microbial fraction. Partitioning of the microbial pool into bacterial and protozoal pools takes into account the differences in ${ }^{15} \mathrm{~N}$ APE between bacteria and protozoa samples, therefore reducing the underestimation bias introduced by assuming bacterial ${ }^{15} \mathrm{~N}$ enrichment as representative of all microbial biomass (Brito et al., 2007). Protozoal predation was estimated using the ${ }^{15} \mathrm{~N}$ enrichment of the microbial fractions as

Engulfed bacterial $\mathrm{N}=$

protozoal $\mathrm{N}$ flow $(\mathrm{g} / \mathrm{d}) \times$ protozoal $^{15} \mathrm{~N}$ APE $(\mathrm{g} / \mathrm{g}) \times 0.9 / 0.5$ bacterial ${ }^{15} \mathrm{~N}$ APE $(\mathrm{g} / \mathrm{g})$ 
In the calculation, we assumed that 90\% of the enriched from ammonia (Williams and Harfoot, 1976; Williams ${ }^{15} \mathrm{~N}$ in the protozoa is of bacterial origin, recognizing the capability of protozoa for de novo synthesis of AA and Coleman, 1997; Newbold et al., 2005). The calculation also assumes that $50 \%$ of the engulfed $\mathrm{N}$ is

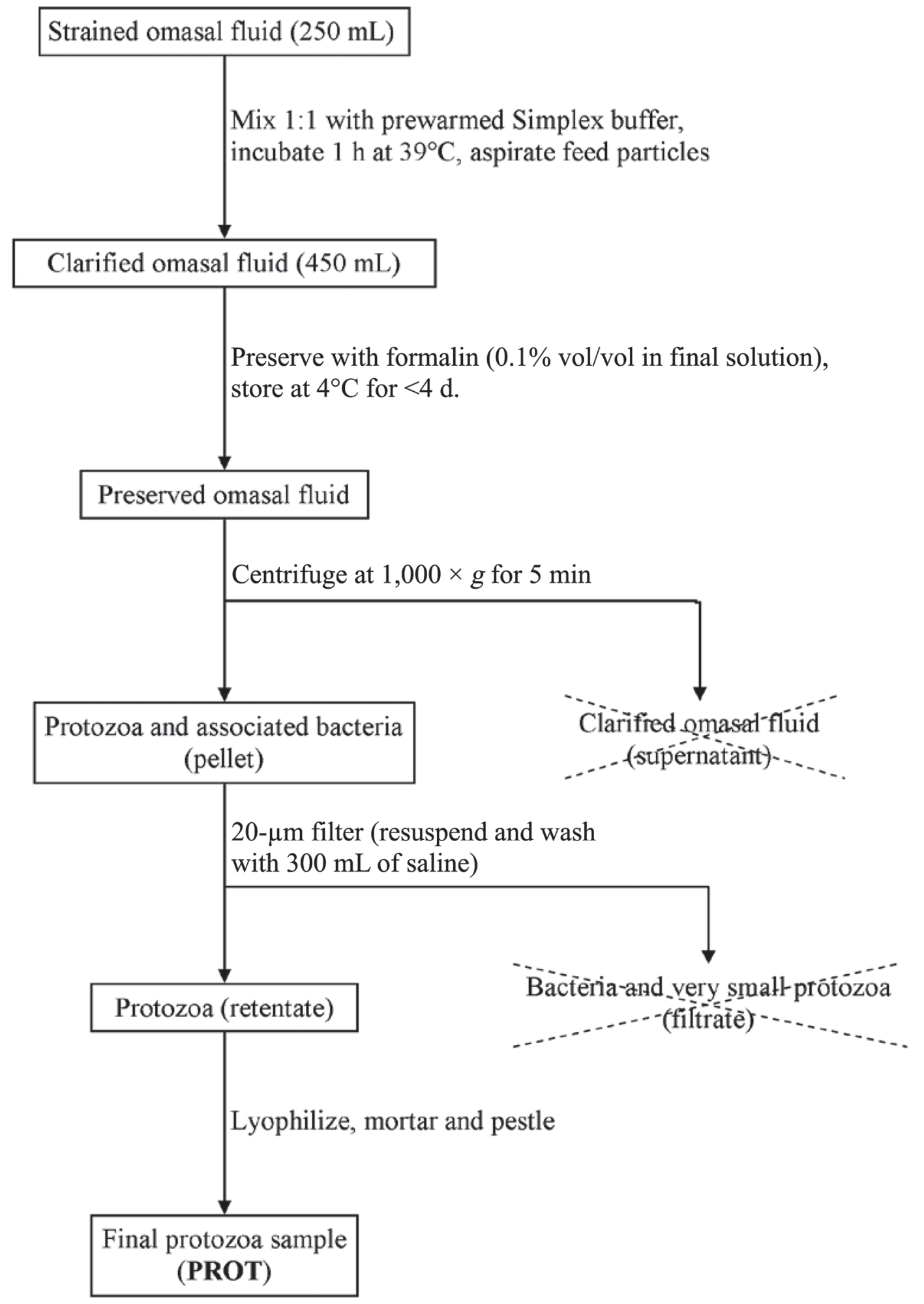

Figure 1. Flowchart for preparation of protozoa isolates with discarded fractions crossed out. Simplex-type buffer made in laboratory (Williams and Coleman, 1992). 
incorporated into cell N (Hristov and Jouany, 2005), an assumption also incorporated into a dynamic version of the CNCPS (Higgs, 2014). Protozoa consumption of bacterial DM and OM was determined using the $\mathrm{N}$ and OM content of the omasal bacteria.

Rumen OM, fermentable carbohydrate (CHO), NAN, and microbial NAN pool sizes were determined from nutrient analysis of the samples taken during the rumen evacuations. Measured ${ }^{15} \mathrm{~N}$ APE of the total rumen NAN pool was used to partition microbial and nonmicrobial $\mathrm{N}$ in the same manner as described for omasal NAN flows. Pool size calculations for digestible $\mathrm{OM}$ and $\mathrm{CHO}$ were

$$
\text { Digestible OM }(\mathrm{kg})=\text { rumen } \mathrm{OM}(\mathrm{kg})-\text { microbial }
$$

OM pool $(\mathrm{kg})$ - rumen uNDFom pool $(\mathrm{kg})$; and

$$
\begin{gathered}
\text { Digestible CHO }(\mathrm{kg})=\text { rumen digestible OM } \\
\text { pool }(\mathrm{kg})-(\text { rumen } \mathrm{CP} \text { pool }- \text { microbial CP pool }) \\
-[\text { rumen DM pool } \times \text { diet fat content }(\mathrm{g} / \mathrm{g} \text { of } \mathrm{DM})]
\end{gathered}
$$

To estimate the partition of the rumen microbial $\mathrm{N}$ pool into bacterial and protozoal pools, relative flows of bacteria and protozoa were multiplied by a factor representing selective retention of protozoa in the rumen. Reported rumen protozoal $\mathrm{N}$ retention in ruminal versus postruminal measurements vary widely, and range from $<5 \%$ (Sylvester et al., 2005) to over $70 \%$ (Punia et al., 1992). Therefore, rumen protozoal ${ }^{15} \mathrm{~N}$ proportion of the total rumen ${ }^{15} \mathrm{~N}$ pool $(\mathbf{P P})$ was calculated at 4 different levels, from no selective retention to $75 \%$ selective retention. To make this estimation, the ratio of protozoal ${ }^{15} \mathrm{~N}$ flow to total omasal ${ }^{15} \mathrm{~N}$ flow was divided by $1,0.75,0.5$, and 0.25 , representing selective retention of $0,25,50$, and $75 \%$, respectively:

$$
\begin{gathered}
\operatorname{PP}(\mathrm{g} / \mathrm{g})=\left[\text { protozoal }{ }^{15} \mathrm{~N} \text { flow }(\mathrm{g} / \mathrm{d}) /\right. \\
\text { OTD } \left.{ }^{15} \mathrm{~N} \text { flow }(\mathrm{g} / \mathrm{d})\right] /(1,0.75,0.5, \text { or } 0.25) .
\end{gathered}
$$

The protozoal proportion of the rumen ${ }^{15} \mathrm{~N}$ at each of the 4 levels of selective retention, along with the APE of rumen contents and the microbial fractions, were then used to calculate the rumen pool sizes for bacterial, protozoal, and total microbial NAN:

$$
\begin{gathered}
\text { Protozoal NAN pool size }(\mathrm{g})= \\
{\left[\text { rumen contents }{ }^{15} \mathrm{~N} \text { APE }(\mathrm{g} / \mathrm{g}) \times \text { rumen total N }(\mathrm{g})\right.} \\
\times \mathrm{PP}(\mathrm{g} / \mathrm{g})] / \text { protozoal }{ }^{15} \mathrm{~N} \text { APE }(\mathrm{g} / \mathrm{g}) ;
\end{gathered}
$$

$$
\text { Bacterial NAN pool size }(\mathrm{g})=
$$

[rumen contents ${ }^{15} \mathrm{~N}$ APE $(\mathrm{g} / \mathrm{g}) \times$ rumen total N $(\mathrm{g})$

$$
\times(1-\mathrm{PP}, \mathrm{g} / \mathrm{g})] / \text { bacterial }{ }^{15} \mathrm{~N} \text { APE }(\mathrm{g} / \mathrm{g}) \text {; and }
$$

Microbial NAN pool size $(\mathrm{g})=$ protozoal NAN pool size $(\mathrm{g})+$ bacterial NAN pool size $(\mathrm{g})$.

The value obtained when using a selective retention rate of $25 \%$ was used in calculations requiring a total rumen microbial pool size. Justification for this approach is discussed later in this paper. Rumen pool size and omasal flow was then used to calculate the fractional growth rate of total microbial, bacterial, and protozoal fractions as

Fractional growth rate $\left(\mathrm{h}^{-1}\right)=$

flow of microbial, bacterial, or protozoal $\mathrm{N}, \mathrm{g} / \mathrm{h}$

rumen pool size of microbial, bacterial, or protozoal N, g .

As flows and pool sizes were measured values, the fractional growth rate accounts for lyses and turnover in the rumen. The same pool size and flow approach was used to calculate the absolute and fractional degradation rates of $\mathrm{OM}$ and $\mathrm{CHO}$ in the rumen, where the numerator was the hourly rate of disappearance of $\mathrm{OM}$ or $\mathrm{CHO}$ and the denominator is the rumen pool size of digestible $\mathrm{OM}$ or $\mathrm{CHO}$. Fractional rate of $\mathrm{CHO}$ degradation and fractional rate of microbial growth was then used to calculate yield of microbial cells per gram of $\mathrm{CHO}$ degraded $\left(\mathbf{Y}_{\mathrm{g}}\right)$ :

$$
\begin{aligned}
& \mathrm{Y}_{\mathrm{g}}(\mathrm{g} \text { of cell } \mathrm{DM} / \mathrm{g} \text { of } \mathrm{CHO} \text { degraded })= \\
& \frac{\text { fractional rate of microbial growth }}{\text { fractional rate of } \mathrm{CHO} \text { degradation }}
\end{aligned}
$$

Flows of individual AA in OTD were calculated using the concentration of AA in each omasal fraction and the triple marker system described in Fessenden et al. (2019). Bacterial, protozoal, total microbial, and nonmicrobial AA flow were then calculated as

$$
\text { Bacterial AA flow }(\mathrm{g} / \mathrm{d})=\text { bacterial } \mathrm{N} \text { flow }(\mathrm{g} / \mathrm{d})
$$$$
\times \text { bacterial AA }(\mathrm{g} / \mathrm{g} \text { of } \mathrm{N}) \text {; }
$$

Protozoal AA flow $(\mathrm{g} / \mathrm{d})=$ protozoal $\mathrm{N}$ flow $(\mathrm{g} / \mathrm{d})$

$$
\times \text { protozoal AA }(\mathrm{g} / \mathrm{g} \text { of } \mathrm{N}) \text {; }
$$

Microbial AA flow $(\mathrm{g} / \mathrm{d})=$ protozoal AA flow $(\mathrm{g} / \mathrm{d})$

$$
+ \text { bacterial AA flow }(\mathrm{g} / \mathrm{d}) \text {; and }
$$


Nonmicrobial AA flow $(\mathrm{g} / \mathrm{d})=$ OTD AA flow $(\mathrm{g} / \mathrm{d})$ - microbial AA flow (g/d).

At the end of the experiment, all relevant farm, cattle, and diet information were entered into an experimental version of the CNCPS v. 7 (Higgs, 2014) to provide comparisons with reported values. The model mechanistically describes substrate degradation using rates of passage and degradation (Waldo et al., 1972), and relates microbial growth to substrate availability (Russell et al., 1992) with modifications (Higgs, 2014). Protozoa, endogenous $\mathrm{N}$ transactions, $\mathrm{N}$ recycling, and large intestine degradation of substrate are all represented in a mechanistic manner. To provide the model with rates of $\mathrm{CHO}$ degradation, feedstuffs were analyzed using methods available from commercial laboratories. The fermentation time points used to calculate the rates of digestion for amylase- and sodium sulfite-treated NDF corrected for ash residue were 30, 120, and $240 \mathrm{~h}$ (Raffrenato et al., 2018). Starch disappearance after $7 \mathrm{~h}$ of in vitro rumen incubation was used to calculate a fractional rate of degradation (Fessenden 2011; Sniffen and Ward 2011). Comparisons were made of model predicted versus measured values for substrate degradation, microbial growth, and postruminal AA flows.

\section{Statistical Analyses}

All data were analyzed using SAS version 9.3 (SAS Institute Inc. Cary, NC). The same model as described in Fessenden et al. (2019) is reproduced here:

$$
\mathrm{Y}_{\mathrm{ijkl}}=\mu+\mathrm{S}_{\mathrm{i}}+\mathrm{C}_{\mathrm{j}: \mathrm{i}}+\mathrm{P}_{\mathrm{k}}+\mathrm{T}_{1}+\mathrm{ST}_{\mathrm{il}}+\varepsilon_{\mathrm{ijkl}},
$$

where $\mathrm{Y}_{\mathrm{ijk}}=$ dependent variable, $\mu=$ overall mean, $\mathrm{S}_{\mathrm{i}}=$ fixed effect of sequence $\mathrm{i}, \mathrm{C}_{\mathrm{j}: \mathrm{i}}=$ random effect of cow within sequence, $\mathrm{P}_{\mathrm{k}}=$ fixed effect of period $\mathrm{k}$, $\mathrm{T}_{1}=$ fixed effect of treatment $1, \mathrm{ST}_{\mathrm{il}}=$ fixed interaction effect of sequence $\mathrm{i}$ and treatment $\mathrm{l}$, and $\varepsilon_{\mathrm{ijkl}}=$ residual error. Degrees of freedom were calculated using the Kenward-Roger option. Means were determined using the least squares means statement, and treatment means were compared using the PDIFF option. Statistical significance was considered at $P \leq 0.05$ and trends were considered at $0.05<P \leq 0.10$.

\section{RESULTS AND DISCUSSION}

\section{Microbial Nutrient Composition}

The OM content of omasal bacteria and protozoa did not differ between diets and averaged 84.1 and $87.6 \%$, respectively (Table 2). Organic matter content was similar to values obtained previously from rumen and omasal isolates (Brito et al., 2006, 2007), although OM content is strongly influenced by the isolation procedures used (Martin et al., 1994). Nitrogen content (\% of DM) of bacteria and protozoa were both affected by diet, with increased $\mathrm{N}$ content in microbial isolates from cows fed EXP. When expressed on an OM basis, protozoal $\mathrm{N}$ did not differ between cows fed EXP or CON. This increased $\mathrm{N}$ content in bacteria could arise from several possible mechanisms. With decreased protein degradation in cows fed EXP as reported in Fessenden et al. (2019), it is possible that less protein was degraded completely to ammonia, thus increasing AA and peptides available for microbial incorporation, leading to increased $\mathrm{N}$ content. Brito et al. (2007) reported a similar 5\% increase in NAN content of fluid-associated bacteria when urea versus true protein supplements were fed to lactating dairy cows. An alternative possibility is a change in microbial reserve carbohydrate synthesis, resulting in more glycogen to dilute the measured NAN value. In microbial competition studies for substrate, Denton et al. (2015) demonstrated that protozoa sequestered up to $60 \%$ of available glucose and stored it as glycogen, whereas less than $2 \%$ was recovered in bacteria. In our study, cows fed CON demonstrated lower microbial N content, which could indicate more reserve CHO synthesis; this could also provide a possible explanation for the relative change in bacterial versus protozoal NAN content when expressed on an OM basis. Bacterial $\mathrm{N}(\% \mathrm{OM})$ increased by $3.5 \%$ (9.45 vs. $9.79 \%$ of OM for cows fed CON vs. EXP, respectively), whereas protozoal NAN content did not differ between diets. Differential amounts of glycogen synthesis by bacteria versus protozoa could lead to the observed result. Omasal protozoal NAN content has been reported as low as $2.3 \%$ of DM (Brito et al., 2006), although sucrose was used in the isolation procedure, likely influencing $\mathrm{N}$ content. The protozoa isolation method employed in the current study deliberately omitted any addition of glycogenic compounds to avoid biasing the $\mathrm{N}$ measurement. Further examination into the rate and extent of uptake of AA and glucogenic precursors by microbial communities might be warranted. Enrichment of ${ }^{15} \mathrm{~N}$ in bacteria and protozoa was similar for cows fed CON versus EXP. The mean protozoal-to-bacterial ${ }^{15} \mathrm{~N}$ enrichment ratio of 0.62 was within the range of values reported in the literature [0.40 (Ahvenjärvi et al., 2002), 0.63 (Hristov and Broderick, 1996), and 0.75 (Cecava et al., 1991)]. Some authors attributed low enrichment to feed contamination in the isolation method, although ${ }^{15} \mathrm{~N}$ enrichment is likely more related to the sources of $\mathrm{N}$ used for growth (Atasoglu et al., 2001; Brito et al., 2006) and possibly the amount of time the bacteria had to take up the label. The approach used in the current experiment followed the concept of a plateau in 
Table 2. Chemical composition and isotopic enrichment of omasal bacteria and protozoa in lactating dairy cattle fed 2 different sources of rumen-available nitrogen

\begin{tabular}{|c|c|c|c|c|}
\hline \multirow[b]{2}{*}{ Item } & \multicolumn{2}{|c|}{ Diet $^{1}$} & \multirow[b]{2}{*}{ SEM } & \multirow[b]{2}{*}{$P$-value } \\
\hline & $\mathrm{CON}$ & EXP & & \\
\hline \multicolumn{5}{|l|}{ Bacteria } \\
\hline $\mathrm{OM}, \%$ of $\mathrm{DM}$ & 83.6 & 84.7 & 0.5 & 0.18 \\
\hline $\mathrm{N}, \%$ of DM & 7.90 & 8.29 & 0.13 & 0.02 \\
\hline $\mathrm{N}, \%$ of $\mathrm{OM}$ & 9.45 & 9.79 & 0.14 & 0.04 \\
\hline${ }^{15} \mathrm{~N}$ atom $\%$ excess & 0.035 & 0.034 & 0.002 & 0.74 \\
\hline Total AA, $\%$ of DM & 28.8 & 30.8 & 0.4 & 0.01 \\
\hline Total AA, $\%$ of OM & 34.3 & 36.3 & 0.4 & 0.02 \\
\hline AA. $\%$ of $N$ & 50.1 & 50.6 & 0.8 & 0.67 \\
\hline \multicolumn{5}{|l|}{ Protozoa } \\
\hline $\mathrm{OM}, \%$ of $\mathrm{DM}$ & 86.1 & 89.1 & 1.5 & 0.17 \\
\hline $\mathrm{N}, \%$ of DM & 7.93 & 8.60 & 0.24 & 0.05 \\
\hline $\mathrm{N}, \%$ of $\mathrm{OM}$ & 9.21 & 9.65 & 0.24 & 0.24 \\
\hline${ }^{15} \mathrm{~N}$ atom $\%$ excess & 0.023 & 0.020 & 0.002 & 0.11 \\
\hline Total AA, $\%$ of DM & 31.4 & 34.4 & 0.9 & 0.02 \\
\hline Total AA, $\%$ of OM & 36.4 & 38.6 & 0.9 & 0.12 \\
\hline $\mathrm{AA}, \%$ of $\mathrm{N}$ & 53.4 & 54.6 & 0.9 & 0.32 \\
\hline
\end{tabular}

${ }^{1} \mathrm{CON}=3 \%$ of diet DM as urea control mix; EXP $=3 \%$ of diet DM as fermentation by-product.

enrichment and cows were infused for $72 \mathrm{~h}$ before any measurements were made (Marini and Van Amburgh, 2003; Recktenwald et al., 2014), thus different enrichment levels were likely not due to nonplateau of ${ }^{15} \mathrm{~N}$. Further, Recktenwald (2010) demonstrated that the rumen $\mathrm{NH}_{3}-\mathrm{N}$ pool reaches equilibrium rapidly after bolus dosing with double-labeled urea. In our study, it is unlikely that relatively small changes in the ammonia pool, as reported in the companion paper (Fessenden et al., 2019), would lead to bias in enrichment measurements due to ${ }^{15} \mathrm{~N}$ dilution.

Total AA content in bacteria and protozoa was increased in cows fed EXP versus CON. Amino acid content as a percent of $\mathrm{N}$ was not different between diets and averaged 50.3 and $54.0 \%$ for omasal bacteria and protozoa, respectively. These values are lower than reported previously in the literature (Storm and Ørskov, 1983). Hvelplund (1986) reported a mean AA N as a percent of $\mathrm{N}$ of $67.4 \%$ in mixed rumen bacteria and demonstrated a curvilinear relationship of diet starch and sugar content versus AA $\mathrm{N}$ as a percent of $\mathrm{N}$, with AA $\mathrm{N}$ decreasing rapidly as starch and sugar content exceeded $30 \%$ of diet DM. Reporting of AA N in the current experiment did not include diaminopimelic acid, which can represent greater that $10 \%$ of the AA content in rumen microorganisms. Another explanation for the lower AA N content of the microbes could be related to the procedure used in this experiment. Formalin has been previously shown to affect the AA composition of isolated cells (Stern et al., 1983), likely through cross-linkage of protein chains. Volden and Harstad (1998) reported an 11\% decrease in total AA $\mathrm{N}$ as a percent of $\mathrm{N}$ when formalin treatment was used in the isolation procedure, with some individual AA such as Lys and Tyr decreasing more than 30\%. Additionally, the formalin treatment can create products resistant even to acid hydrolysis, rendering incomplete extraction of AA from the sample matrix (Barry, 1976; Fessenden et al., 2017). Therefore, bacterial and protozoal AA profiles and contributions to AA flow might be underestimated in our study; however, total flow of AA in OTD is unaffected, as no formalin was used in the separation of LQ, SP, or LP fractions. Overall, these data on AA $\mathrm{N}$ composition of microbes suggest the use of formalin in the isolation procedure should be eliminated if AA analysis and composition is an objective of the experiment.

Omasal bacterial and protozoal AA composition were unaffected by diet (Table 3). Profiles of bacterial AA generally agree well with literature reports (Volden et al., 1999) with the exception of Lys and Tyr, which were decreased in the current study; formalin is known to specifically affect these AA (Volden and Harstad, 1998). The protozoal AA profile was similar when compared with bacterial AA profile, with the exception of Met and Lys showing numerically increased levels in protozoa. Volden et al. (1999) also reported increased Lys concentration in protozoa versus bacteria; however, Met was very similar between isolates in their study. Cockburn and Williams (1984) reported mean Met concentrations of $2.4 \mathrm{~g} / 100 \mathrm{~g}$ of AA, which is very consistent with the average value of the 2 treatments in our study, $2.45 \mathrm{~g} / 100 \mathrm{~g}$ of AA. Inconsistent use and poor reporting of preoxidation procedures used among studies makes many comparisons of sulfur AA difficult, as recoveries from preoxidation are rarely reported (Spindler et al., 1984). It is possible that formalin treatment increased the relative proportion of Met in our microbial isolates; 
however, this effect should also be distributed across other AA not affected by formalin treatment.

\section{Omasal Flows of AA in OTD, Microbial, and Nonmicrobial Fractions}

Microbial nutrient flow of DM, OM, and NAN were was not different between diets (Table 4). Effects of RDP source on omasal nutrient flows have been previously described in Fessenden et al. (2019). Cows fed CON versus EXP tended to have increased bacterial $\mathrm{DM}$ and $\mathrm{OM}$ flow (4,808 vs. 4,056 g of DM/d and 4,023 vs. $3,433 \mathrm{~g}$ of $\mathrm{OM} / \mathrm{d}$ for CON vs. EXP, respectively). As bacterial OM and DM flow are calculated using microbial $\mathrm{N}$ as a marker, it is likely that the observed difference in microbial $\mathrm{N}$ composition contributed to lower calculated DM and OM flows. Protozoal nutrient flows followed similar numeric trends, but flows did not differ significantly between diets. Protozoa accounted for 15.8 and $17.9 \%$ of the total microbial NAN flow in cows fed CON versus EXP, respectively. This estimate is slightly higher than has previously been reported in the literature with animals at similar levels of intake. Sylvester et al. (2005) reported protozoal N accounting for 5.9 to $11.9 \%$ of the microbial $\mathrm{N}$ flow using $18 \mathrm{~S}$ rDNA techniques, whereas Ahvenjärvi et al. (2002) reported $7 \%$ of microbial $\mathrm{N}$ flow as protozoal $\mathrm{N}$ using a very similar technique to our study, albeit with widely differ- ing diets. Very few studies attempt to directly measure protozoal flows due to the difficulty of the approach. As such, some researchers have taken alternative approaches to estimate protozoal contribution to the microbial $\mathrm{N}$ pool. Using a linear programming approach, Shabi et al. (2000) estimated protozoal $\mathrm{N}$ to account for 7 to $19 \%$ of microbial $\mathrm{N}$ flow. This was a result similar to that estimated by Steinhour et al. (1982) using a differential ${ }^{15} \mathrm{~N}$ enrichment approach, although many assumptions were made pertaining to pool size and turnover in that study. Alternatively, computer simulations by Dijkstra et al. (1998) indicated that protozoal $\mathrm{N}$ could account for 10.7 to $26.1 \%$ of microbial $\mathrm{N}$ in cattle at $17.1 \mathrm{~kg}$ of DMI. Simulations using CNCPS v. 7 (Higgs, 2014) indicated that overall microbial flow in cows fed CON was well predicted; however, the model was insensitive to the numerical difference in microbial flow in cows fed CON versus EXP (Table 4), as protozoal flow (g/d) was underpredicted by $43 \%$. It is possible that the coefficients used to calculate protozoa growth are relatively low, as they are often based on in vitro studies of the more easily cultured protozoal species (Coleman and Hall, 1984; Coleman, 1992). The rates of substrate uptake and growth reported in vitro experiments might be considerably lower than those achieved in the rumen. It is also possible that the predictions of protozoa passage from the rumen are not correct in CNCPS v. 7 because few data exist on which to build robust equations and

Table 3. Omasal bacterial and protozoal AA composition in lactating dairy cattle fed 2 different sources of rumen-available nitrogen

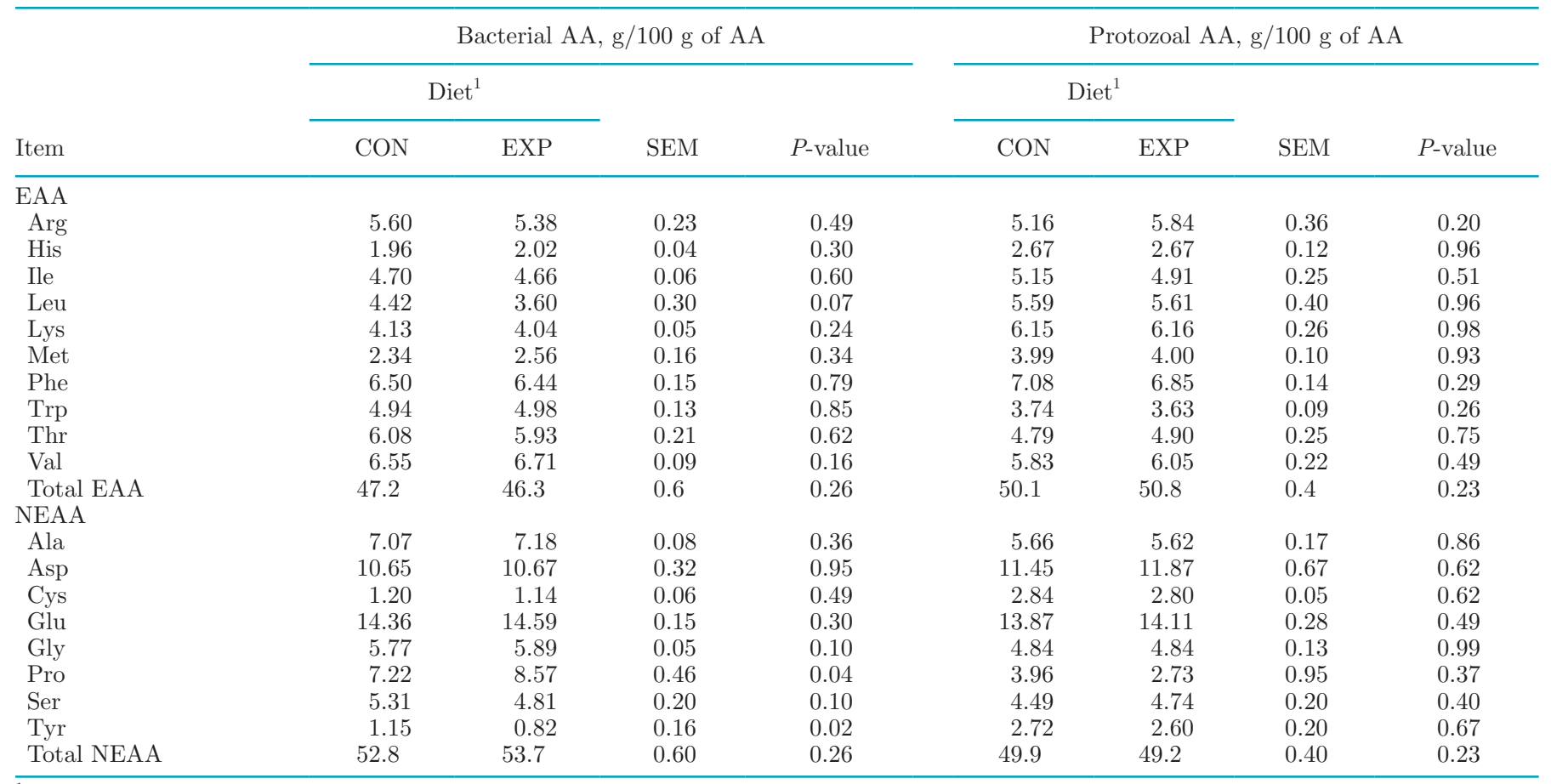

${ }^{1} \mathrm{CON}=3 \%$ of diet DM as urea control mix; $\mathrm{EXP}=3 \%$ of diet DM as fermentation by-product. 
Table 4. Omasal microbial nutrient flows and protozoal predation in lactating dairy cattle fed 2 different sources of rumen-available nitrogen

\begin{tabular}{|c|c|c|c|c|}
\hline \multirow[b]{2}{*}{ Item } & \multicolumn{2}{|c|}{$\operatorname{Diet}^{1}$} & \multirow[b]{2}{*}{ SEM } & \multirow[b]{2}{*}{$P$-value } \\
\hline & $\mathrm{CON}$ & EXP & & \\
\hline DMI, $\mathrm{kg} / \mathrm{d}^{2}$ & 23.8 & 23.9 & 0.7 & 0.91 \\
\hline \multicolumn{5}{|l|}{ Total microbial nutrient flow, $\mathrm{g} / \mathrm{d}$} \\
\hline DM flow & 5,718 & 4,930 & 358 & 0.14 \\
\hline OM flow & 4,815 & 4,210 & 310 & 0.19 \\
\hline NAN flow ${ }^{2}$ & 450 & 409 & 28 & 0.31 \\
\hline \multicolumn{5}{|l|}{ Bacterial nutrient flow, $\mathrm{g} / \mathrm{d}$} \\
\hline DM flow & 4,808 & 4,056 & 286 & 0.08 \\
\hline OM flow & 4,023 & 3,433 & 240 & 0.10 \\
\hline NAN flow & 378 & 337 & 23.0 & 0.22 \\
\hline$\%$ of microbial $\mathrm{N}$ flow & 84.2 & 82.1 & 1.0 & 0.12 \\
\hline \multicolumn{5}{|l|}{ Protozoal nutrient flow, $\mathrm{g} / \mathrm{d}$} \\
\hline DM flow & 909 & 850 & 82 & 0.61 \\
\hline OM flow & 790 & 764 & 81 & 0.82 \\
\hline NAN flow & 72.1 & 73.9 & 7.3 & 0.84 \\
\hline$\%$ of microbial $\mathrm{N}$ flow & 15.8 & 17.9 & 1.0 & 0.12 \\
\hline \multicolumn{5}{|l|}{ Protozoal predation of bacteria, $\mathrm{g} / \mathrm{d}$} \\
\hline DM consumed & 1,159 & 929 & 166 & 0.33 \\
\hline OM consumed & 967 & 783 & 138 & 0.35 \\
\hline $\mathrm{N}$ consumed & 90.6 & 76.3 & 12.9 & 0.45 \\
\hline$\%$ of bacterial $\mathrm{N}$ flow & 23.4 & 22.2 & 2.4 & 0.70 \\
\hline \multicolumn{5}{|l|}{ 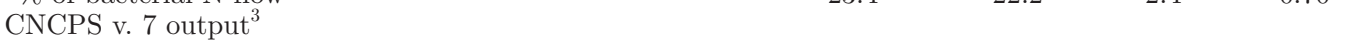 } \\
\hline Predicted microbial N flow, $\mathrm{g} / \mathrm{d}$ & 412 & 417 & - & - \\
\hline Bacterial N flow & 371 & 375 & - & - \\
\hline Protozoal N flow & 41 & 42 & - & - \\
\hline$\%$ of microbial $\mathrm{N}$ flow & 9.9 & 10.1 & - & - \\
\hline Predation estimate, bacterial N consumed, $\mathrm{g} / \mathrm{d}$ & 75 & 76 & - & - \\
\hline
\end{tabular}

${ }^{1} \mathrm{CON}=3 \%$ of diet DM as urea control mix; EXP $=3 \%$ of diet DM as fermentation by-product.

${ }^{2}$ Previously reported in Fessenden et al. (2019).

${ }^{3}$ Higgs (2014).

the model structure uses particle passage as a basis although protozoa might be passing in the liquid phase, which would lead to underestimations. Future studies measuring microbial $\mathrm{N}$ flows should report protozoal contribution to the microbial flow, as data in this area are lacking.

The flow of AA in OTD is presented in Table 5. Most AA demonstrated increased flow in cows fed EXP versus CON. Total AA flow was increased by $211 \mathrm{~g} / \mathrm{d}$ in cows fed EXP compared with CON (2,456 vs. 2,245 $\mathrm{g} / \mathrm{d}$ for CON vs. EXP, respectively; $P<0.01$ ). Omasal flow of Lys, Met, and Phe were similar between diets, whereas all other EAA were increased in cows fed EXP compared with CON. Total NEAA flow was increased by $116 \mathrm{~g} / \mathrm{d}$ in cows fed EXP, whereas Cys flow was the only individual NEAA that was similar between diets. Reynal and Broderick (2005) reported similar results in omasal AA flows when diets with varying RDP from soybean meal versus treated soybean meal were fed to lactating dairy cows. When soybean meal, cottonseed meal, and canola meal were compared with a urea control, flows of all AA increased greatly in a study by Brito et al. (2007). The increase in AA flows in the current study was directly related to the lower dietary CP degradation in cows fed EXP, as reported by Fessenden et al. (2019). It is notable that although total NAN flow was not different between diets, total AA flow was increased in cows fed fermentation by-product; this would suggest that the NAN flow in cows fed the CON diets might have a higher content of non-AA nitrogenous compounds. The observed results might also occur if AA with higher $\mathrm{N}$ content are preferentially degraded in the rumen of cows fed fermentation by-products, thus reducing the measured NAN flow. Overall, fermentation by-products inclusion increased nonmicrobial AA flow relative to control (Table 6). Inclusion of the fermentation by-product had no effect on microbial AA flow, whereas nonmicrobial AA flow was increased for most individual AA. This further supports the protein-sparing effect of the fermentation by-product on RDP, as microbial AA flow was not significantly lower but nonmicrobial AA flow increased by $316 \mathrm{~g} / \mathrm{d}$ in cows fed EXP compared with CON $(P=$ $0.03)$. Microbial protein synthesis was apparently not negatively affected by decreased $\mathrm{CP}$ degradation, indicating that sufficient AA and $\mathrm{N}$ compounds were present to support high rates of microbial growth. It should be noted that the nonmicrobial AA flows presented in 
Table 5. Effect of rumen-available nitrogen source on omasal true digesta flow of AA in lactating dairy cattle

\begin{tabular}{lrrrr}
\hline & \multicolumn{2}{c}{ Diet $^{1}$} & & \\
\cline { 2 - 3 } AA flow, g/d & CON & EXP & SEM & P-value \\
\hline EAA & & & & \\
Arg & 108.2 & 120.1 & 3.4 & 0.01 \\
His & 62.2 & 68.0 & 1.5 & $<0.01$ \\
Ile & 87.3 & 100.2 & 2.7 & $<0.01$ \\
Leu & 131.0 & 149.2 & 7.0 & 0.03 \\
Lys & 139.0 & 127.4 & 14.0 & 0.56 \\
Met & 57.3 & 57.3 & 5.5 & 1.00 \\
Phe & 147.7 & 165.8 & 8.3 & 0.11 \\
Trp & 78.9 & 86.3 & 2.4 & $<0.01$ \\
Thr & 119.9 & 131.6 & 3.3 & $<0.01$ \\
Val & 116.8 & 131.1 & 3.6 & $<0.01$ \\
Total EAA & $1,045.8$ & $1,141.8$ & 28.4 & 0.03 \\
NEAA & & & $<0.01$ \\
Ala & 140.9 & 153.0 & 4.0 & $<0.01$ \\
Asp & 212.3 & 236.2 & 5.7 & 0.78 \\
Cys & 39.3 & 38.0 & 3.4 & $<0.01$ \\
Glu & 280.1 & 314.0 & 6.3 & 0.03 \\
Gly & 105.9 & 116.5 & 2.7 & $<0.01$ \\
Pro & 172.1 & 189.4 & 6.2 & $<.05$ \\
Ser & 120.0 & 131.4 & 3.3 & $<0.01$ \\
Tyr & 130.4 & 138.7 & 4.4 & 31.4 \\
Total NEAA & $1,200.9$ & $1,316.8$ & 57.1 & \\
Total AA & $2,245.2$ & $2,456.5$ & & \\
\hline
\end{tabular}

${ }^{1} \mathrm{CON}=3 \%$ of diet DM as urea control mix; $\mathrm{EXP}=3 \%$ of diet DM as fermentation by-product.

Table 6 are calculated by subtraction of microbial AA flow from total AA flow. As such, experimental and measurement errors will be disproportionally represent- ed in the reported nonmicrobial AA flows. This might also lead to values for individual AA that are outside biologically expected ranges. This occurred with Trp,

Table 6. Effect of rumen-available nitrogen source on omasal flow of microbial and nonmicrobial AA in lactating dairy cattle

\begin{tabular}{|c|c|c|c|c|c|c|c|c|}
\hline \multirow[b]{3}{*}{ Item } & \multicolumn{4}{|c|}{ Microbial AA flow, g/d } & \multicolumn{4}{|c|}{ Nonmicrobial AA flow, g/d } \\
\hline & \multicolumn{2}{|c|}{$\operatorname{Diet}^{1}$} & \multirow[b]{2}{*}{ SEM } & \multirow[b]{2}{*}{$P$-value } & \multicolumn{2}{|c|}{ Diet $^{1}$} & \multirow[b]{2}{*}{ SEM } & \multirow[b]{2}{*}{$P$-value } \\
\hline & $\mathrm{CON}$ & EXP & & & $\mathrm{CON}$ & EXP & & \\
\hline \multicolumn{9}{|l|}{ EAA } \\
\hline Arg & 96.9 & 88.4 & 6.7 & 0.38 & 10.7 & 31.8 & 7.9 & 0.08 \\
\hline His & 36.4 & 34.7 & 2.3 & 0.57 & 25.8 & 33.2 & 2.7 & 0.04 \\
\hline Ile & 83.1 & 75.4 & 5.7 & 0.34 & 4.2 & 23.4 & 6.4 & 0.01 \\
\hline Leu & 79.5 & 61.7 & 6.3 & 0.06 & 52.9 & 87.9 & 9.7 & 0.02 \\
\hline Lys & 78.4 & 71.9 & 5.8 & 0.42 & 60.5 & 56.3 & 14.7 & 0.84 \\
\hline Met & 43.1 & 44.8 & 3.4 & 0.67 & 14.0 & 12.8 & 6.1 & 0.88 \\
\hline Phe & 114.0 & 103.0 & 7.8 & 0.35 & 33.4 & 61.9 & 10.4 & 0.06 \\
\hline $\operatorname{Trp}$ & 82.7 & 74.5 & 5.2 & 0.28 & - & 11.4 & 6.7 & - \\
\hline Thr & 103.3 & 92.9 & 7.8 & 0.35 & 16.4 & 37.0 & 8.9 & 0.05 \\
\hline Val & 112.4 & 106.3 & 8.0 & 0.58 & 4.3 & 23.1 & 10.0 & 0.09 \\
\hline Total EAA & 830.2 & 749.0 & 51.4 & 0.28 & 213.6 & 371.7 & 64.6 & 0.04 \\
\hline \multicolumn{9}{|l|}{ NEAA } \\
\hline Ala & 119.8 & 111.2 & 8.0 & 0.43 & 20.5 & 40.5 & 9.7 & 0.07 \\
\hline Asp & 188.7 & 177.8 & 13.8 & 0.51 & 23.1 & 56.7 & 15.5 & 0.04 \\
\hline Cys & 24.8 & 23.0 & 1.5 & 0.34 & 14.4 & 15.3 & 3.7 & 0.86 \\
\hline Glu & 249.8 & 234.9 & 17.7 & 0.51 & 30.0 & 76.7 & 19.9 & 0.04 \\
\hline Gly & 98.1 & 91.7 & 6.8 & 0.48 & 7.6 & 23.7 & 7.8 & 0.08 \\
\hline Pro & 117.0 & 122.1 & 9.6 & 0.66 & 55.7 & 65.8 & 12.7 & 0.42 \\
\hline Ser & 90.5 & 79.5 & 6.7 & 0.17 & 29.5 & 50.7 & 8.3 & $<0.01$ \\
\hline Tyr & 24.2 & 19.4 & 2.5 & 0.09 & 106.2 & 119.1 & 4.4 & $<0.01$ \\
\hline Total NEAA & 913.1 & 861.0 & 61.7 & 0.49 & 287.1 & 445.6 & 73.7 & 0.03 \\
\hline Total AA & $1,744.2$ & $1,611.4$ & 113.9 & 0.39 & 500.0 & 815.9 & 135.4 & 0.03 \\
\hline
\end{tabular}

${ }^{1} \mathrm{CON}=3 \%$ of diet DM as urea control mix; EXP $=3 \%$ of diet DM as fermentation by-product. 
Table 7. Effect of rumen-available nitrogen source on omasal flow of bacterial and protozoal AA flow in lactating dairy cattle

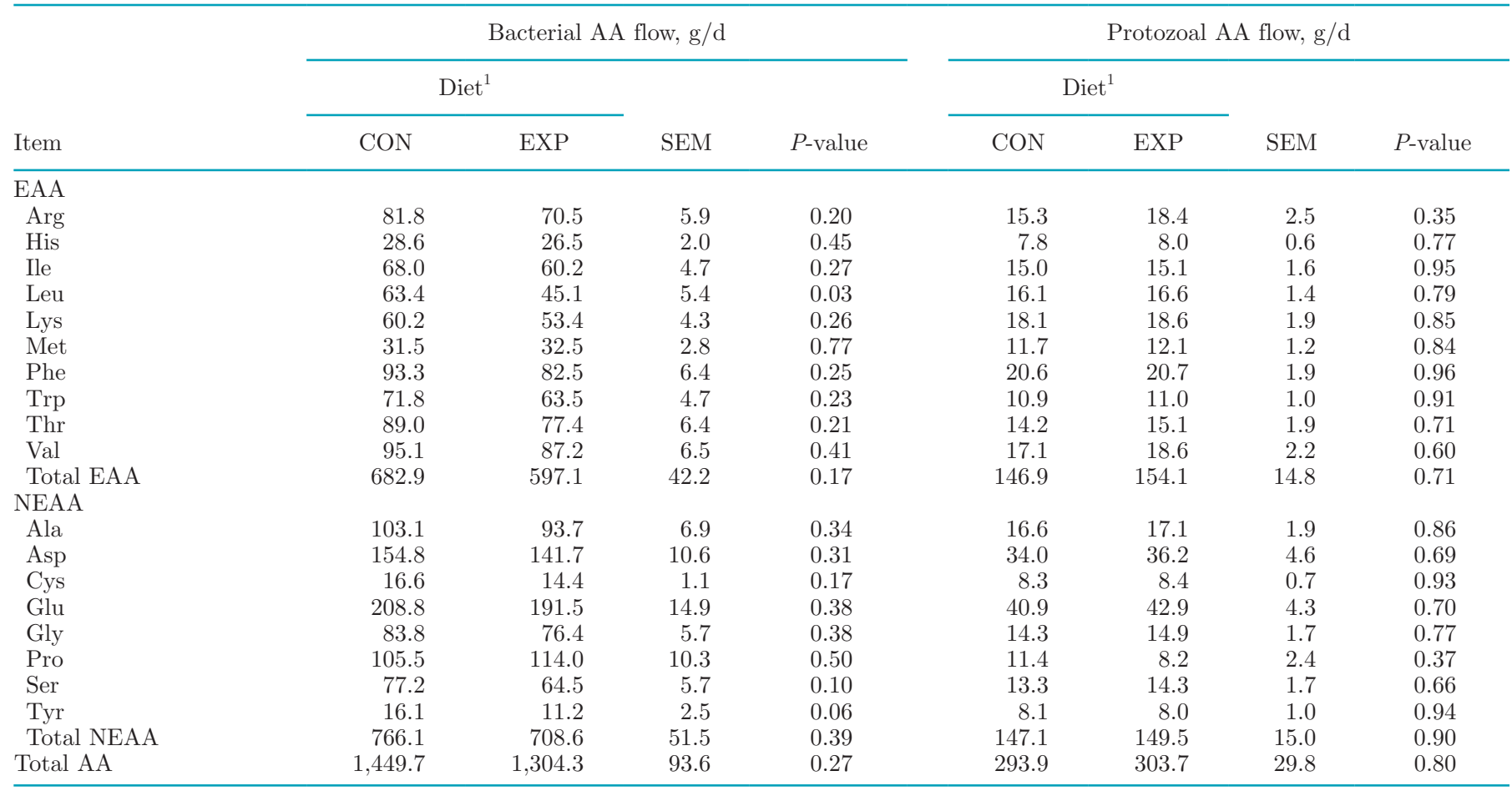

${ }^{1} \mathrm{CON}=3 \%$ of diet DM as urea control mix; EXP $=3 \%$ of diet DM as fermentation by-product.

where the flow (determined by difference of total AA flow vs. microbial AA flow) would result in a negative number.

\section{Omasal Flows of AA in Bacteria and Protozoa}

Flows of individual AA in bacterial and protozoal fractions were generally not affected by diet (Table 7). Bacterial Leu flow was increased in cows fed CON versus EXP (63.4 vs. $45.1 \mathrm{~g} / \mathrm{d}$ for CON vs. EXP, respectively; $P=0.03)$. Bacterial Ser and Tyr flows tended to be increased in cows fed CON versus EXP, whereas all other bacterial AA flows were not different between diets. Protozoal AA flows were unaffected by treatment. The contribution of protozoa to total microbial AA flow is in Table 8. Inclusion of the fermentation by-product in the EXP diets increased protozoa contribution to Leu and Lys flow. Protozoa flow of Lys accounted for 21.5 versus $29.5 \%$ of the total microbial flow of Lys in cows fed EXP versus CON, respectively $(P<0.01)$. Contribution of protozoa to total EAA flow tended to be greater in cows fed EXP versus CON (19.0 vs. $22.8 \%$ of microbial flow, respectively; $P=0.07$ ). These results demonstrate the importance of protozoa to postruminal AA flows. Protozoal NAN contribution to microbial NAN flows averaged $16.9 \%$ of microbial $\mathrm{N}$, whereas the contribution of protozoal AA to microbial AA flows ranged from 8 to $46 \%$ for individual AA. Models that do not take into account the difference in AA profile, composition, and contribution of protozoa to microbial AA flow might have poor predictions of postruminal AA flow. For models seeking to describe the diet adequacy to support milk protein production, accurate predictions of postruminal supply are needed if the models are to be applied in practical feeding situations (Pacheco et al., 2012). Higgs (2014) evaluated CNCPS v. 7 against a large literature data set and found the model adequately predicts postruminal total NAN and microbial NAN supply; however, individual AA were generally over-predicted. The same tendency to overpredict AA flow was observed in the current evaluation might be indicative of mean bias of the model or could be related to a methodological bias associated with the use of the triple-marker system, as all studies in the data set used this approach.

\section{Rumen Pool Size and Kinetics of OM, CHO, |Bacteria, and Protozoa}

Rumen pool sizes of digestible OM, CHO, NAN, and microbial NAN were not affected by diet (Table 9). Generally, the microbial N pool size of $3.5 \mathrm{~g}$ of microbial N/L was similar to that observed by Sylvester et al. (2005), who reported a microbial pool of approximately $3.0 \mathrm{~g}$ of microbial $\mathrm{N} / \mathrm{L}$, although those authors point out that the estimation of bacterial $\mathrm{N}$ contains the er- 
ror of both the $18 \mathrm{~S}$ RNA procedure and the purine determination. Purines have been shown to be inconsistent microbial markers relative to ${ }^{15} \mathrm{~N}$ (Klopfenstein et al., 2001; Firkins and Reynolds, 2005; Ipharraguerre et al., 2007). Cows fed CON had a greater microbial DM contribution to the total DM pool than cows fed EXP (27.7 vs. $23.6 \%$ for CON vs. EXP, respectively; $P$ $=0.05)$. The values in this experiment were within the range of 17 to $27 \%$ of the rumen DM pool as microbial DM reported by Craig et al. (1987).

Selective retention of protozoa in the rumen is not well understood, and estimates range from $<5 \%$ (Sylvester et al., 2005) to over $70 \%$ (Punia et al., 1992). As rumen protozoal mass was not quantified directly in our study, the effect of 4 different levels of retention is described in Table 9. Further, as total rumen microbial pool size was estimated from ${ }^{15} \mathrm{~N}$ enrichment of the rumen NAN pool, it is possible to evaluate the effect of selective retention on pool sizes, assuming total microbial ${ }^{15} \mathrm{~N}$ pool size remains constant. Therefore, at $0 \%$ selective retention, we expect the protozoa to account for the same proportion of total rumen microbial $\mathrm{N}$ as measured in OTD flow, whereas at greater levels of retention protozoa account for larger portions of the microbial pool. Bacterial pool size was decreased in cows fed EXP versus CON, and bacterial versus protozoal pool sizes diverged as estimated selective retention increased. At the highest estimation of selective retention, protozoa were calculated to represent 55 to $58 \%$ of the total microbial pool (CON vs. EXP, respectively, $P=0.40)$.

To assess which level of selective retention of protozoa is likely most correct, it was possible to use pool size and flow to estimate fractional rates of turnover (Table 10). In this case, as actual flows and microbial pool size were measured, the rate of turnover of the pool can be used as an index of microbial growth rate (Wells and Russell, 1996). Recognizing that the main energy substrate for rumen bacteria is CHO (Russell et al., 1992), and assuming the maximum yield of cell DM per gram of CHO degraded is 0.5 (Isaacson et al., 1975), one can quickly determine which retention values allows for realistic growth rates. In this instance, selective retention at $50 \%$ indicate that bacteria would have to grow at a fractional rate of $0.07 \mathrm{~h}^{-1}$, corresponding to a $\mathrm{CHO}$ degradation rate of $0.14 \mathrm{~h}^{-1}(0.07 / 0.5)$. Given the estimated pool size $(\mathrm{g})$ and digestion $(\mathrm{g} / \mathrm{h})$, the fractional rate of $\mathrm{CHO}$ availability in our study averaged 0.138 $\mathrm{h}^{-1}$ of the available pool; therefore, theoretical maximal fractional growth rate was estimated at $0.138 \times$ 0.5 or $\sim 0.069 \mathrm{~h}^{-1}$. Using the measured total microbial pool at $25 \%$ selective retention, it was calculated that the fractional growth rate of all microbes in the rumen was $0.061 \mathrm{~h}^{-1}$. This corresponds to an estimated $\mathrm{Y}_{\mathrm{g}}$ of $0.44 \mathrm{~g} / \mathrm{g}$ of $\mathrm{CHO}$ degraded; this value is close to the theoretical maximums for individual species reported in pure cultures (Russell and Baldwin, 1979; Theodorou and France, 2005). In vitro measurements of mixed ru-

Table 8. Effect of rumen-available nitrogen source on protozoal proportion of omasal microbial AA flow in lactating dairy cattle

\begin{tabular}{|c|c|c|c|c|}
\hline \multirow{2}{*}{$\begin{array}{l}\text { Protozoal AA contribution } \\
\text { to microbial AA flow, } \%\end{array}$} & \multicolumn{2}{|c|}{ Diet $^{1}$} & \multirow[b]{2}{*}{ SEM } & \multirow[b]{2}{*}{$P$-value } \\
\hline & $\mathrm{CON}$ & EXP & & \\
\hline \multicolumn{5}{|l|}{ EAA } \\
\hline Arg & 17.0 & 22.0 & 2.0 & 0.07 \\
\hline His & 22.5 & 25.9 & 1.7 & 0.18 \\
\hline Ile & 18.8 & 21.5 & 1.6 & 0.15 \\
\hline Leu & 21.5 & 29.5 & 1.6 & $<0.01$ \\
\hline Lys & 23.9 & 28.2 & 1.6 & 0.05 \\
\hline Met & 28.6 & 31.3 & 2.5 & 0.46 \\
\hline Phe & 19.0 & 22.0 & 1.7 & 0.22 \\
\hline Trp & 17.8 & 24.4 & 4.1 & 0.27 \\
\hline Thr & 14.7 & 17.8 & 1.5 & 0.15 \\
\hline Val & 16.0 & 19.0 & 1.4 & 0.17 \\
\hline Total EAA & 19.0 & 22.8 & 1.5 & 0.07 \\
\hline \multicolumn{5}{|l|}{ NEAA } \\
\hline Ala & 14.7 & 17.1 & 1.4 & 0.25 \\
\hline Asp & 18.9 & 22.6 & 1.8 & 0.09 \\
\hline Cys & 34.4 & 40.0 & 2.4 & 0.11 \\
\hline Glu & 17.2 & 20.1 & 1.5 & 0.15 \\
\hline Gly & 15.2 & 17.8 & 1.5 & 0.23 \\
\hline Pro & 10.6 & 7.7 & 2.7 & 0.46 \\
\hline Ser & 15.6 & 21.0 & 1.7 & 0.04 \\
\hline Tyr & 35.4 & 45.8 & 5.5 & 0.21 \\
\hline Total NEAA & 16.8 & 19.4 & 1.3 & 0.20 \\
\hline Total AA & 17.8 & 20.9 & 1.4 & 0.13 \\
\hline
\end{tabular}

${ }^{1} \mathrm{CON}=3 \%$ of diet DM as urea control mix; EXP $=3 \%$ of diet DM as fermentation by-product. 
men microbes often give yields on the high range of those observed in pure culture (Russell and Wallace, 1997). The range of yields (29 to $100 \mathrm{~g} / \mathrm{mol}$ of hexose) reported by Russell and Wallace (1997) correspond to $\mathrm{Y}_{\mathrm{g}}$ of 0.16 to $0.55 \mathrm{~g} / \mathrm{g}$ of glucose degraded. Stouthamer (1973) estimated a maximal $\mathrm{Y}_{\mathrm{g}}$ of approximately 0.8 $\mathrm{g} / \mathrm{g}$ of glucose using biochemical pathways, indicating the possibility for much higher yields in some bacterial species; however, values this high are rarely reported in vitro with mixed rumen microbial fermentations. It is possible that higher growth rates could be achieved in vivo, as it can be very difficult to maintain ideal conditions for microbial growth outside the rumen.

The CNCPS relates cell growth directly to $\mathrm{CHO}$ availability in the manner described above, making accurate estimates of $\mathrm{CHO}$ degradation key to accurately predicting microbial yield. Simulations indicated that the model characterized $\mathrm{CHO}$ digestion reasonably well (Table 10), with predicted absolute rates of degradation approximately $37 \mathrm{~g}$ lower than observed; this corresponds to a fractional rate of degradation of $\mathrm{CHO}$ at $0.124 \mathrm{~h}^{-1}$. Given the predicted microbial yield (Table 4), the apparent $\mathrm{Y}_{\mathrm{g}}$ used by the model was 0.45 $\mathrm{g} / \mathrm{g}$ of $\mathrm{CHO}$ degraded in the rumen, very similar to the value observed in vivo. Unfortunately, many other in vivo studies investigating rumen outflows do not report rumen pool sizes or individual microbial popula- tions, thereby limiting the utility of the data for model evaluation. Even so, the limited data presented here show good agreement of predicted versus independent measured values, indicating that the structure of the model is likely adequate to provide accurate estimates of microbial yield from substrate degradation. This provides a strong basis from which to improve AA supply predictions, as microbial AA represents a large portion of metabolizable AA flowing from the rumen.

\section{CONCLUSIONS}

The inclusion of the fermentation by-product in EXP diets increased microbial $\mathrm{N}$ and AA N flows compared with CON cows fed a urea control. Microbial AA composition did not differ between diets; however, estimates of total AA N and specific AA were likely lower than literature values due to formalin treatment. Daily flows of AA were increased in OTD as a result of decreased degradation of feed N, as reported by Fessenden et al. (2019). This was reflected in the current study with increased nonmicrobial AA flow in cows fed EXP veruss CON. Average protozoal contribution to microbial NAN flow was $16.8 \%$, yet protozoal AA accounted for $21 \%$ of the microbial EAA flow, with a range of 8 to $46 \%$ for individual AA. Cows in this study maintained an average pool size of $320 \mathrm{~g}$ of microbial $\mathrm{N}$ in the

Table 9. Effect of rumen-available nitrogen source on rumen pool sizes of OM, carbohydrate (CHO), and NAN in lactating dairy cattle

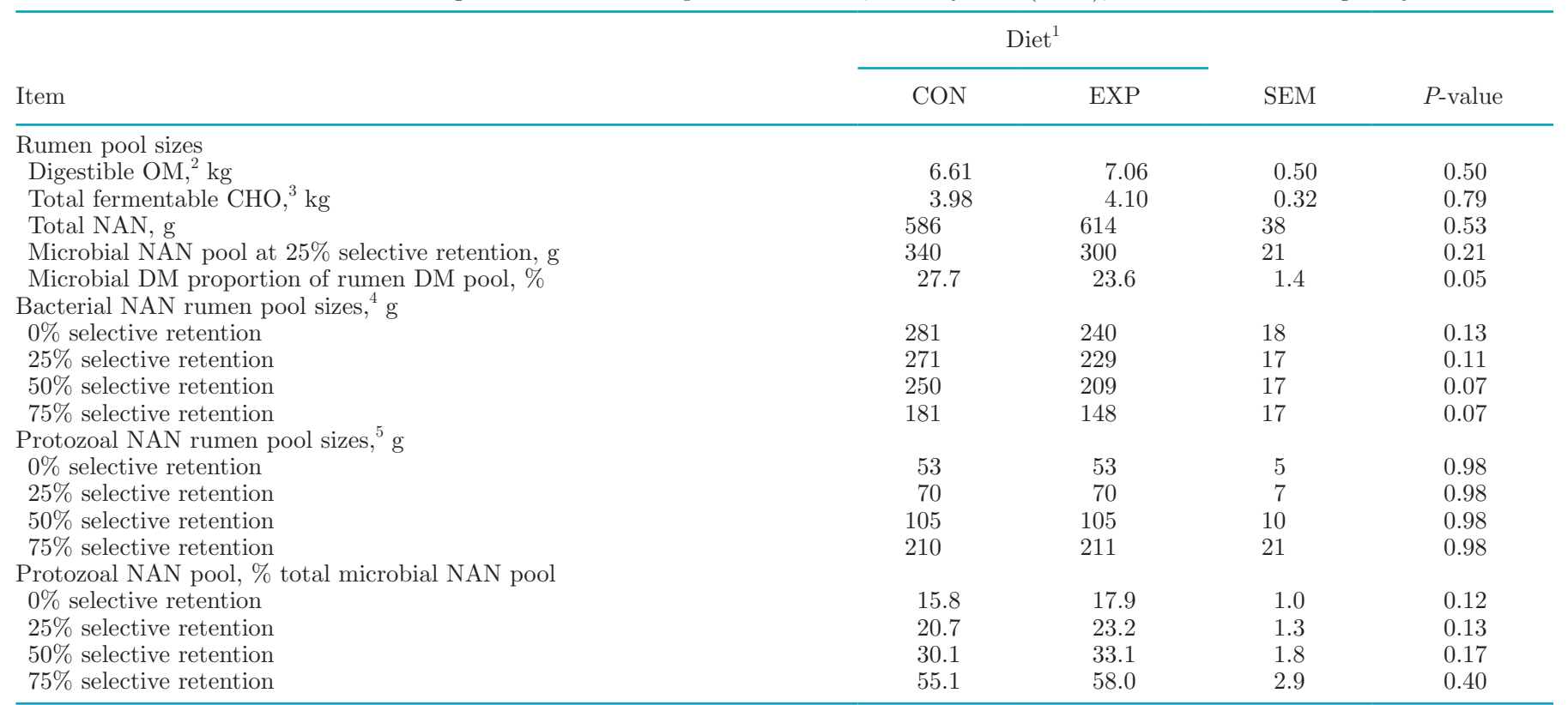

${ }^{1} \mathrm{CON}=3 \%$ of diet DM as urea control mix; EXP $=3 \%$ of diet DM as fermentation by-product.

${ }^{2}$ Measured OM from rumen evacuation, corrected for microbial OM and undigested NDF after $240 \mathrm{~h}$ of in vitro digestion and analyzed with amylase, sodium sulfite and ash corrected (Raffrenato et al., 2018).

${ }^{3}$ Rumen OM pool - (rumen CP pool - microbial CP pool) $-($ rumen DM pool $\times$ diet fat content $)$.

${ }^{4}$ Microbial NAN pool - protozoal NAN pool at 4 levels of selective retention of protozoa.

${ }^{5}$ Microbial NAN $\times$ protozoal $\%$ of omasal flow $\times$ level of selective retention. 
Table 10. Fractional rates of microbial growth, nutrient digestion, and rumen fermentation parameters in lactating dairy cattle fed 2 different sources of rumen-available nitrogen

\begin{tabular}{|c|c|c|c|c|}
\hline \multirow[b]{2}{*}{ Item } & \multicolumn{2}{|c|}{$\operatorname{Diet}^{1}$} & \multirow[b]{2}{*}{ SEM } & \multirow[b]{2}{*}{$P$-value } \\
\hline & $\mathrm{CON}$ & EXP & & \\
\hline $0 \%$ selective retention & 0.061 & 0.061 & 0.004 & 0.99 \\
\hline $25 \%$ selective retention & 0.064 & 0.064 & 0.005 & 0.99 \\
\hline $50 \%$ selective retention & 0.070 & 0.070 & 0.006 & 1.00 \\
\hline $75 \%$ selective retention & 0.108 & 0.103 & 0.012 & 0.74 \\
\hline $25 \%$ selective retention & 0.046 & 0.046 & 0.003 & 0.99 \\
\hline $50 \%$ selective retention & 0.030 & 0.030 & 0.002 & 0.99 \\
\hline $75 \%$ selective retention & 0.015 & 0.015 & 0.001 & 0.99 \\
\hline \multicolumn{5}{|l|}{ Omasal flows and ruminal digestion parameters } \\
\hline True OM flow, ${ }^{3} \mathrm{~kg} / \mathrm{d}$ & 7.08 & 7.19 & 0.47 & 0.87 \\
\hline Microbial NAN flow, ${ }^{3} \mathrm{~g} / \mathrm{d}$ & 450 & 409 & 28 & 0.31 \\
\hline Ruminal true OM digestion rate, $\mathrm{g} / \mathrm{h}$ & 626 & 619 & 17 & 0.77 \\
\hline Theoretical maximum CHO allowable growth, ${ }^{5} \mathrm{~h}^{-1}$ & 0.070 & 0.069 & 0.005 & 0.91 \\
\hline Observed $\mathrm{Yg},{ }^{6} \mathrm{~g}$ of cells/g of $\mathrm{CHO}$ degraded & 0.44 & 0.44 & 0.03 & 0.99 \\
\hline$\%$ of theoretical maximum $\mathrm{Yg}$ & 88.4 & 88.3 & 6.6 & 0.99 \\
\hline \multicolumn{5}{|l|}{ CNCPS v. 7 output $^{7}$} \\
\hline Predicted $\mathrm{CHO}$ degradation, $\mathrm{g} / \mathrm{h}$ & 484 & 487 & - & - \\
\hline Predicted fractional rate of CHO digestion, $\mathrm{h}^{-1}$ & 0.124 & 0.124 & - & - \\
\hline Predicted $\mathrm{Yg}, \mathrm{g}$ of cells/g of CHO degraded & 0.45 & 0.45 & - & - \\
\hline
\end{tabular}

${ }^{1} \mathrm{CON}=3 \%$ of diet DM as urea control mix; EXP $=3 \%$ of diet DM as fermentation by-product.

${ }^{2}$ Bacterial or protozoal daily flow $(\mathrm{g} / \mathrm{h}) /$ bacterial or protozoal pool size $(\mathrm{g})$ at 4 levels of protozoa selective retention.

${ }^{3}$ Previously reported in Fessenden et al. (2019).

${ }^{4}$ Measured microbial NAN flow $(\mathrm{g} / \mathrm{h}) /$ measured rumen microbial NAN pool $(\mathrm{g})$.

${ }^{5}$ Fractional rate of carbohydrate $(\mathrm{CHO})$ digestion $\times 0.5$.

${ }^{6}$ Fractional microbial growth rate/fractional rate of $\mathrm{CHO}$ digestion.

${ }^{7}$ Higgs (2014).

rumen, whereas bacterial and protozoal pools were estimated at 4 different theoretical levels of retention. Fractional growth rate of all microbes in the rumen was measured at $0.069 \mathrm{~h}^{-1}$, with a $\mathrm{Yg}$ of $0.44 \mathrm{~g} / \mathrm{g}$ of $\mathrm{CHO}$ degraded. A dynamic versions of the CNCPS v. 7 was able to accurately predict $\mathrm{CHO}$ degradation and total microbial yield, but improvements are needed for bacterial versus protozoal partitioning and individual AA flow predictions. Overall, the current structure of the CNCPS v. 7 provides a strong base for predicting supply of microbial NAN. Future model improvements in microbial AA profiles, intestinal digestibility, protozoal partitioning, and dietary protein degradation might be needed to improve estimates of individual AA flow.

\section{ACKNOWLEDGMENTS}

The authors thank Arm and Hammer Animal Nutrition for funding support; A. Zontini, A. LaPierre, and M. Horton (Cornell University, Ithaca, NY) for assist- ing with sample collection, processing, and analysis; and the research staff and farm crew at the Cornell University Ruminant Center (Harford NY), especially W. Prokop, L. Furman, and Z. Leno. Portions of this manuscript appear in S. Fessenden's doctoral dissertation (Fessenden, 2016) and conference proceedings (Fessenden and Van Amburgh, 2016).

\section{REFERENCES}

Ahvenjärvi, S., A. Vanhatalo, and P. Huhtanen. 2002. Supplementing barley or rapeseed meal to dairy cows fed grass-red clover silage: I. Rumen degradability and microbial flow. J. Anim. Sci. 80:21762187. https://doi.org/10.2527/2002.8082176x.

AOAC International. 2005. Official Methods of Analysis. 18th ed. AOAC International, Gaithersburg, MD.

Atasoglu, C., C. J. Newbold, and R. J. Wallace. 2001. Incorporation of $[15 \mathrm{~N}]$ ammonia by the cellulolytic ruminal bacteria Fibrobacter succinogenes BL2, Ruminococcus albus SY3, and Ruminococcus flavefaciens 17. Appl. Environ. Microbiol. 67:2819-2822. https://doi .org/10.1128/AEM.67.6.2819-2822.2001.

Barry, T. N. 1976. The effectiveness of formaldehyde treatment in protecting dietary protein from rumen microbial degradation. Proc. Nutr. Soc. 35:221-229. https://doi.org/10.1079/PNS19760035. 
Brito, A. F., G. A. Broderick, and S. M. Reynal. 2006. Effect of varying dietary ratios of alfalfa silage to corn silage on omasal flow and microbial protein synthesis in dairy cows. J. Dairy Sci. 89:39393953. https://doi.org/10.3168/jds.S0022-0302(06)72436-5.

Brito, A. F., G. A. Broderick, and S. M. Reynal. 2007. Effects of different protein supplements on omasal nutrient flow and microbial protein synthesis in lactating dairy cows. J. Dairy Sci. 90:18281841. https://doi.org/10.3168/jds.2006-559.

Broderick, G. A., N. De Leon, and Y. Nakamura. 2000. Potential of fermentation by-products as nitrogen supplements for lactating dairy cows. J. Dairy Sci. 83:2548-2556. https://doi.org/10.3168/ jds.S0022-0302(00)75147-2.

Cecava, M. J., N. Merchen, L. Berger, R. Mackie, and G. Fahey. 1991. Effects of dietary energy level and protein source on nutrient digestion and ruminal nitrogen metabolism in steers. J. Anim. Sci. 69:2230-2243. https://doi.org/10.2527/1991.6952230x.

Cockburn, J. E., and A. P. Williams. 1984. The simultaneous estimation of the amounts of protozoal, bacterial and dietary nitrogen entering the duodenum of steers. Br. J. Nutr. 51:111-132. https:/ /doi.org/10.1079/BJN19840014.

Coleman, G. S. 1992. The rate of uptake and metabolism of starch grains and cellulose particles by Entodinium species, Eudiplodinium maggii, some other entodiniomorphid protozoa and natural protozoal populations taken from the ovine rumen. J. Appl. Bacteriol. 73:507-513. https://doi.org/10.1111/j.1365-2672.1992.tb05013.x.

Coleman, G. S., and F. J. Hall. 1984. The uptake and utilization of entodinium caudatum, bacteria, free amino acids and glucose by the rumen ciliate entodinium bursa. J. Appl. Bacteriol. 56:283-294. https://doi.org/10.1111/j.1365-2672.1984.tb01349.x.

Cotta, M. A., and J. B. Russell. 1982. Effect of peptides and amino acids on efficiency of rumen bacterial protein synthesis in continuous culture. J. Dairy Sci. 65:226-234. https://doi.org/10.3168/jds .S0022-0302(82)82181-4.

Craig, W. M., G. A. Broderick, and D. B. Ricker. 1987. Quantitation of microorganisms associated with the particulate phase of ruminal ingesta. J. Nutr. 117:56-62.

Denton, B. L., L. E. Diese, J. L. Firkins, and T. J. Hackmann. 2015. Accumulation of reserve carbohydrate by rumen protozoa and bacteria in competition for glucose. Appl. Environ. Microbiol. 81:1832-1838. https://doi.org/10.1128/AEM.03736-14.

Dijkstra, J., J. France, and S. Tamminga. 1998. Quantification of the recycling of microbial nitrogen in the rumen using a mechanistic model of rumen fermentation processes. J. Agric. Sci. 130:81-94.

Elkin, R. G., and J. Griffith. 1985. Hydrolysate preparation for analysis of amino acids in sorghum grains: Effect of oxidative pretreatment. J. Assoc. Off. Anal. Chem. 68:1117-1121.

Fessenden, S. W. 2011. Effects of corn prolamin content on in vitro starch digestibility as measured by various methods. BS Honors Thesis, Department of Animal Science, Cornell Univ., Ithaca, NY.

Fessenden, S. W. 2016. Amino acid supply in dairy cattle. PhD Dissertation. Animal Science, Cornell Univ., Ithaca, NY. https:// ecommons.cornell.edu/handle/1813/45365.

Fessenden, S. W., A. Foskolos, T. J. Hackmann, D. A. Ross, E. Block, and M. E. Van Amburgh. 2019. Rumen digestion kinetics, microbial yield, and omasal flows of non-microbial and microbial amino acids in lactating dairy cattle fed fermentation byproduct or urea as a soluble nitrogen source. J. Dairy Sci. 102:3023-3035. https:// doi.org/10.3168/jds.2018-15447.

Fessenden, S. W., T. J. Hackmann, D. A. Ross, A. Foskolos, and M. E. Van Amburgh. 2017. Ruminal bacteria and protozoa composition, digestibility, and amino acid profile determined by multiple hydrolysis times. J. Dairy Sci. 100:7211-7226. https://doi.org/10 .3168/jds.2016-12531.

Fessenden, S. W., and M. E. Van Amburgh. 2016. Characterization of non-nutritive factors of feeds for model development. Pages 155-169 in Proc. Cornell Nutrition Conference, Syracuse, NY. Cornell University, Ithaca, NY. Accessed Mar. 15, 2017. https:// ecommons.cornell.edu/handle/1813/44741.

Firkins, J. L., and C. K. Reynolds. 2005. Whole animal nitrogen balance in cattle. Pages 167-185 in Nitrogen and Phosphorus Nutrition of Cattle: Reducing the Environmental Impact of Cattle
Operations. E. Pfeffer and A. N. Hristov, ed. CAB International, Wallingford, UK.

France, J., and R. Siddons. 1986. Determination of digesta flow by continuous market infusion. J. Theor. Biol. 121:105-119. https:// doi.org/10.1016/S0022-5193(86)80031-5.

Gehrke, C. W., L. Wall Sr., J. Absheer, F. Kaiser, and R. Zumwalt. 1985. Sample preparation for chromatography of amino acids: Acid hydrolysis of proteins. J. Assoc. Off. Anal. Chem. 68:811-821.

Higgs, R. 2014. Development of a dynamic rumen and gastro-intestinal model in the Cornell Net Carbohydrate and Protein System to predict the nutrient supply and requirements of dairy cattle. PhD Dissertation. Department of Animal Science, Cornell Univ., Ithaca, NY.

Higgs, R. J., L. Chase, D. Ross, and M. Van Amburgh. 2015. Updating the Cornell Net Carbohydrate and Protein System feed library and analyzing model sensitivity to feed inputs. J. Dairy Sci. 98:63406360. https://doi.org/10.3168/jds.2015-9379.

Hristov, A. N., and G. A. Broderick. 1996. Synthesis of microbial protein in ruminally cannulated cows fed alfalfa silage, alfalfa hay, or corn silage. J. Dairy Sci. 79:1627-1637. https://doi.org/10.3168/ jds.S0022-0302(96)76526-8.

Hristov, A. N., and J.-P. Jouany. 2005. Nitrogen requirements of cattle. Pages 117-166 in Factors Affecting the Efficiency of Nitrogen Utilization in the Rumen. A. Pfeffer and A. N. Hristov, ed. CABI, Wallingford, UK.

Huhtanen, P., P. G. Brotz, and L. D. Satter. 1997. Omasal sampling technique for assessing fermentative digestion in the forestomach of dairy cows. J. Anim. Sci. 75:1380-1392. https://doi.org/10 $.2527 / 1997.7551380 \mathrm{x}$.

Hvelplund, T. 1986. The influence of diet on nitrogen and amino acid content of mixed rumen bacteria. Acta Agric. Scand. 36:325-331. https://doi.org/10.1080/00015128609436535.

Ipharraguerre, I. R., S. M. Reynal, M. Lineiro, G. A. Broderick, and J. H. Clark. 2007. A comparison of sampling sites, digesta and microbial markers, and microbial references for assessing the postruminal supply of nutrients in dairy cows. J. Dairy Sci. 90:1904-1919. https://doi.org/10.3168/jds.2006-159.

Isaacson, H. R., F. C. Hinds, M. P. Bryant, and F. N. Owens. 1975. Efficiency of energy utilization by mixed rumen bacteria in continuous culture. J. Dairy Sci. 58:1645-1659. https://doi.org/10.3168/ jds.S0022-0302(75)84763-1.

Klopfenstein, T. J., R. A. Mass, K. W. Creighton, and H. H. Patterson. 2001. Estimating forage protein degradation in the rumen. J. Anim. Sci. 79:E208-E216. https://doi.org/10.2527/jas2001.79E -SupplE208x.

Landry, J., and S. Delhaye. 1992. Simplified procedure for the determination of tryptophan of foods and feedstuffs from barytic hydrolysis. J. Agric. Food Chem. 40:776-779. https://doi.org/10 $.1021 / \mathrm{jf00017a014}$.

Lean, I. J., T. K. Webster, W. Hoover, W. Chalupa, C. J. Sniffen, E. Evans, E. Block, and A. R. Rabiee. 2005. Effects of BioChlor and Fermenten on microbial protein synthesis in continuous culture fermenters. J. Dairy Sci. 88:2524-2536. https://doi.org/10.3168/ jds.S0022-0302(05)72930-1.

Lobley, G. E., D. Bremner, and G. Zuur. 2000. Effects of diet quality on urea fates in sheep as assessed by refined, non-invasive [15N15N] urea kinetics. Br. J. Nutr. 84:459-468. https://doi.org/ $10.1017 /$ S0007114500001768.

Marini, J. C., and M. E. Van Amburgh. 2003. Nitrogen metabolism and recycling in Holstein heifers. J. Anim. Sci. 81:545-552. https:/ /doi.org/10.2527/2003.812545x.

Martin, C., A. G. Williams, and B. Michalet-Doreau. 1994. Isolation and characteristics of the protozoal and bacterial fractions from bovine ruminal contents. J. Anim. Sci. 72:2962-2968. https://doi .org/10.2527/1994.72112962x.

Mason, V. C., S. Bech-Andersen, and M. Rudemo. 1980. Hydrolysate preparation for amino acid determinations in feed constituents. Z. Tierphysiol. Tierernahr. Futtermittelkd. 43:35-48. https://doi .org/10.1111/j.1439-0396.1980.tb00618.x.

Newbold, C. J., N. R. McEwan, R. E. Calza, E. N. Chareyron, S. M. Duval, S. C. Eschenlauer, F. M. McIntosh, N. Nelson, A. J. Travis, 
and R. J. Wallace. 2005. An NAD+-dependent glutamate dehydrogenase cloned from the ruminal ciliate protozoan, Entodinium caudatum. FEMS Microbiol. Lett. 247:113-121. https://doi.org/10 .1016/j.femsle.2005.04.034

Pacheco, D., R. A. Patton, C. Parys, and H. Lapierre. 2012. Ability of commercially available dairy ration programs to predict duodenal flows of protein and essential amino acids in dairy cows. J. Dairy Sci. 95:937-963. https://doi.org/10.3168/jds.2011-4171.

Penner, G. B., L. Guan, and M. Oba. 2009. Effects of feeding Fermenten on ruminal fermentation in lactating Holstein cows fed two dietary sugar concentrations. J. Dairy Sci. 92:1725-1733. https:// doi.org/10.3168/jds.2008-1706.

Punia, B. S., J. Leibholz, and G. J. Faichney. 1992. Rate of production of protozoa in the rumen and the flow of protozoal nitrogen to the duodenum in sheep and cattle given a pelleted diet of lucerne hay and barley. J. Agric. Sci. 118:229-236.

Raffrenato, E., D. A. Ross, and M. E. Van Amburgh. 2018. Development of an in vitro method to determine rumen undigested aNDFom for use in feed evaluation. J. Dairy Sci. 101:9888-9900. https: //doi.org/10.3168/jds.2018-15101.

Recktenwald, E. B. 2010. Urea N recycling and its utilization by ruminal microbial populations in lactating dairy cattle. $\mathrm{PhD}$ Dissertation, Department of Animal Science, Cornell Univ., Ithaca, NY.

Recktenwald, E. B., D. A. Ross, S. W. Fessenden, C. J. Wall, and M. E. Van Amburgh. 2014. Urea N recycling in lactating dairy cows fed diets with 2 different levels of dietary crude protein and starch with or without monensin. J. Dairy Sci. 97:1611-1622. https://doi .org/10.3168/jds.2013-7162.

Reynal, S. M., and G. A. Broderick. 2005. Effect of dietary level of rumen-degraded protein on production and nitrogen metabolism in lactating dairy cows. J. Dairy Sci. 88:4045-4064. https://doi .org/10.3168/jds.S0022-0302(05)73090-3.

Russell, J., and R. Wallace. 1997. Energy-yielding and energy-consuming reactions. Pages 246-282 in The Rumen Microbial Ecosystem. 2nd ed. P. N. Hobson and C. S. Stewart, ed. Blackie Academic \& Professional, New York, NY.

Russell, J. B., and R. L. Baldwin. 1979. Comparison of maintenance energy expenditures and growth yields among several rumen bacteria grown on continuous culture. Appl. Environ. Microbiol. $37: 537-543$.

Russell, J. B., J. D. O'Connor, D. G. Fox, P. J. Van Soest, and C. J. Sniffen. 1992. A net carbohydrate and protein system for evaluating cattle diets: I. Ruminal fermentation. J. Anim. Sci. 70:35513561. https://doi.org/10.2527/1992.70113551x.

Shabi, Z., H. Tagari, M. R. Murphy, I. Bruckental, S. J. Mabjeesh, S. Zamwel, K. Celik, and A. Arieli. 2000. Partitioning of amino acids flowing to the abomasum into feed, bacterial, protozoal, and endogenous fractions. J. Dairy Sci. 83:2326-2334. https://doi.org/ 10.3168/jds.S0022-0302(00)75120-4.

Siddons, R. C., J. Paradine, D. E. Beever, and P. R. Cornell. 1985. Ytterbium acetate as a particulate-phase digesta-flow marker. Br. J. Nutr. 54:509-519. https://doi.org/10.1079/BJN19850136.

Sniffen, C. J., and R. Ward. 2011. Using starch digestibility information in ration balancing. Pages 121-133 in Proc. Western Canadian Dairy Seminar: Advances in Dairy Technology, Red Deer, AB, Canada. University of Alberta, Edmonton, AB, Canada.

Spindler, M., R. Stadler, and H. Tanner. 1984. Amino acid analysis of feedstuffs: Determination of methionine and cystine after oxidation with performic acid and hydrolysis. J. Agric. Food Chem. 32:1366-1371. https://doi.org/10.1021/jf00126a038.

Steinhour, W. D., M. Stokes, J. Clark, J. Rogers, C. Davis, and D. Nelson. 1982. Estimation of the proportion of non-ammonia-nitrogen reaching the lower gut of the ruminant derived from bacterial and protozoal nitrogen. Br. J. Nutr. 48:417-431. https://doi.org/10 $.1079 / B J N 19820124$.

Stern, M. D., L. M. Rode, R. W. Prange, R. H. Stauffacher, and L. D. Satter. 1983. Ruminal protein degradation of corn gluten meal in lactating dairy cattle fitted with duodenal t-type cannulae. J. Anim. Sci. 56:194-205.

Storm, E., and E. R. Ørskov. 1983. The nutritive value of rumen micro-organisms in ruminants 1. Large-scale isolation and chemical composition of rumen micro-organisms. Br. J. Nutr. 50:463-470. https://doi.org/10.1079/BJN19830114.

Stouthamer, A. H. 1973. A theoretical study on the amount of ATP required for synthesis of microbial cell material. Antonie van Leeuwenhoek 39:545-565. https://doi.org/10.1007/BF02578899.

Sylvester, J. T., S. K. R. Karnati, Z. Yu, C. J. Newbold, and J. L. Firkins. 2005. Evaluation of a real-time PCR assay quantifying the ruminal pool size and duodenal flow of protozoal nitrogen. J. Dairy Sci. 88:2083-2095. https://doi.org/10.3168/jds.S0022 $-0302(05) 72885-\mathrm{X}$.

Theodorou, M., and J. France. 2005. Rumen microorganisms and their interactions. Pages 145-163 in Quantitative Aspects of Ruminant Digestion and Metabolism J. M. Forbes and J. France, ed. CAB International, Wallingford, UK.

Tylutki, T. P., D. G. Fox, V. M. Durbal, L. O. Tedeschi, J. B. Russell, M. E. Van Amburgh, T. R. Overton, L. E. Chase, and A. N. Pell. 2008. Cornell Net Carbohydrate and Protein System: A model for precision feeding of dairy cattle. Anim. Feed Sci. Technol. 143:174202. https://doi.org/10.1016/j.anifeedsci.2007.05.010.

Udén, P., P. E. Colucci, and P. J. Van Soest. 1980. Investigation of chromium, cerium and cobalt as markers in digesta. Rate of passage studies. J. Sci. Food Agric. 31:625-632. https://doi.org/10 $.1002 /$ jsfa. 2740310702 .

Van Amburgh, M. E., E. Collao-Saenz, R. Higgs, D. Ross, E. Recktenwald, E. Raffrenato, L. Chase, T. Overton, J. Mills, and A. Foskolos. 2015. The Cornell Net Carbohydrate and Protein System: Updates to the model and evaluation of version 6.5. J. Dairy Sci. 98:6361-6380. https://doi.org/10.3168/jds.2015-9378.

VandeHaar, M. J., and N. St-Pierre. 2006. Major advances in nutrition: Relevance to the sustainability of the dairy industry. J. Dairy Sci. 89:1280-1291. https://doi.org/10.3168/jds.S0022 $-0302(06) 72196-8$.

Volden, H., and O. M. Harstad. 1998. Amino acid composition of bacteria harvested from the rumen of dairy cows fed three diets differing in protein content and rumen protein degradability at two levels of intake. Acta Agric. Scand. A Anim. Sci. 48:210-215. https://doi.org/10.1080/09064709809362422.

Volden, H., O. M. Harstad, and L. T. Mydland. 1999. Amino acid content and profile of protozoal and bacterial fractions isolated from ruminal contents of lactating dairy cows fed diets differing in nitrogen supplementation. Acta Agric. Scand. A Anim. Sci. 49:245-250. https://doi.org/10.1080/090647099424006.

Waldo, D. R., L. W. Smith, and E. L. Cox. 1972. Model of cellulose disappearance from the rumen. J. Dairy Sci. 55:125-129. https:// doi.org/10.3168/jds.S0022-0302(72)85442-0.

Wells, J. E., and J. B. Russell. 1996. Why do many ruminal bacteria die and lyse so quickly? J. Dairy Sci. 79:1487-1495. https://doi .org/10.3168/jds.S0022-0302(96)76508-6.

Whitehouse, N. L., V. Olson, C. Schwab, W. Chesbrot, K. Cunningham, and T. Lykos. 1994. Improved techniques for dissociating particle-associated mixed ruminal microorganisms from ruminal digesta solids. J. Anim. Sci. 72:1335-1343. https://doi.org/10 $.2527 / 1994.7251335 x$.

Williams, A. G., and G. S. Coleman. 1992. The Rumen Protozoa. Springer-Verlag, New York, NY.

Williams, A. G., and G. S. Coleman. 1997. The rumen protozoa. Pages 73-139 in The Rumen Microbial Ecosystem. P. N. Hobson and C. S. Stewart, ed. Elsevier Science Publishers Ltd., London, UK.

Williams, A. G., and C. G. Harfoot. 1976. Factors affecting the uptake and metabolism of soluble carbohydrates by the rumen ciliate Dasytricha ruminantium isolated from ovine rumen contents by filtration. J. Gen. Microbiol. 96:125-136. https://doi.org/10.1099/ 00221287-96-1-125. 